Chapman University

Chapman University Digital Commons

Economics Faculty Articles and Research

Economics

1983

\title{
OCS Leasing and Auctions: Incentives and the Performance of Alternative Bidding Institutions
}

James W. Cox

University of Maryland

R. Mark Isaac

Florida State University

Vernon L. Smith

Chapman University, vsmith@chapman.edu

Follow this and additional works at: http://digitalcommons.chapman.edu/economics_articles

Part of the Economics Commons, and the Law Commons

\section{Recommended Citation}

Cox, James W., R. Mark Isaac, and Vernon L. Smith. "OCS Leasing and Auctions: Incentives and the Performance of Alternative Bidding Institutions." Supreme Court Economic Review, 2 (1983): 43-87.

This Article is brought to you for free and open access by the Economics at Chapman University Digital Commons. It has been accepted for inclusion in Economics Faculty Articles and Research by an authorized administrator of Chapman University Digital Commons. For more information, please contactlaughtin@chapman.edu. 


\title{
OCS Leasing and Auctions: Incentives and the Performance of Alternative Bidding Institutions
}

\author{
Comments \\ This article was originally published in Supreme Court Economic Review, volume 2, in 1983.
}

\section{Copyright}

University of Chicago 


\title{
OCS LEASING AND AUCTIONS: INCENTIVES AND THE PERFORMANCE OF ALTERNATIVE BIDDING INSTITUTIONS
}

\author{
James C. Cox* \\ R. Mark Isaac** \\ Vernon L. Smith***
}

In Watt v. Energy Action Educational Foundation, the Supreme Court rebutted a challenge to the federal government's mix of "nontraditional" outer continental shelf lease-auction mechanisms authorized under the 1978 OCS Amendments. The issues of this case addressed here include: the economic intent of the congressional language; incentive properties of various of the authorized auction processes; methodological shortcomings inherent in the implicit congressional directive for field experimentation; and, the usefulness of laboratory experimental economics in answering relevant auction-policy questions. The discussion of experimental economics includes evidence already gained from laboratory experiments relating to hypotheses about auction-market performance.

On December 1, 1981, the Supreme Court decided Watt v. Energy Action Educational Foundation. ${ }^{1}$ The suit was based on the Outer Continental Shelf Lands Act Amendments of 1978. ${ }^{2}$ The plaintiffs, including the State of California and several consumer groups, had brought suit against the Secretary of the Interior, asking for a declaratory judgment that the governmental entities involved had abused their legislated discretion in not experimenting with bidding systems that use other than cash bonuses as bidding variables. The plaintiffs also asked for an injunction against further outer continental shelf (hereinafter OCS) lease sales until new regulations had been issued for the alternative systems, and for a prohibition of further sales based on a fixed-royalty and variable cash-bonus bid.

This essay examines some economic aspects of alternative auctionmarket institutions, with special reference to alternative methods for the auctioning of oil and gas exploration and development rights on OCS

*Professor of Economics, University of Arizona; B.A., University of California at Davis, 1965; M.A., Harvard University, 1968; Ph.D., 1971.

**Assistant Professor of Economics, University of Arizona; B.S.F.S., Georgetown University, 1976; M.S., California Institute of Technology, 1978; Ph.D., 1981.

$* * *$ Professor of Economics, University of Arizona; B.S., California Institute of Technology, 1949; M.A., University of Kansas, 1951; Ph.D., Harvard University, 1955. 


\section{Supreme Court Economic Review}

lands. Our discussion is motivated by some of the economic aspects of the issues raised in Energy Action, and we offer some analyses of the implications of bidding on different dimensions of the OCS leases. But, the economic and methodological issues that this case raises are much broader than the particular bidding systems involved. These issues include questions concerning what constitutes an experiment, what can be learned from experiments, what incentives alternative auction institutions provide for the bidders, and how these incentives affect the resulting prices and allocations. ${ }^{3}$

Section I briefly reviews some of the issues raised in the pleadings and in the Court's decision. Section II evaluates certain theoretical properties of the alternative auction rules, with particular emphasis on some theoretical implications of these alternatives for the development of OCS leases. The original legislation, the Department of Energy regulations, the litigants' pleadings, and the Supreme Court's ruling all raise fundamental methodological issues regarding the empirical evaluation of hypotheses about the relative merits of alternative auction processes. Consequently, Section III explores an issue implicit in the wording of the original legislation, namely the evaluation of auctions in some kind of "field" experiment undertaken by the federal government. Section III also explores some generic limitations on any such field inquiry. Section IV discusses an alternative method of evaluating auction institutions, namely the use of laboratory experiments. Laboratory experiments are complementary, and, we argue, in some respects superior, to field experimentation. We present examples from the existing experimental literature on auction markets for two purposes: to demonstrate what researchers have already learned about auction markets in the laboratory, and to suggest what other kinds of issues directly relevant to OCS leasing might be amenable to laboratory testing. Sections III and IV provide important methodological and empirical background for further experimentation based on the special characteristics of OCS leasing. Finally, Section V offers some concluding comments.

\section{LEGISLATIVE GOALS AND ECONOMIC THEORY}

\section{A. General Overview}

The policies at issue in Energy Action have their genesis in the Outer Continental Shelf Lands Act Amendments of 1978 (hereinafter, the 1978 Amendments). ${ }^{4}$ In this legislation Congress directed that the federal government experiment with several "nontraditional" methods of auctioning OCS oil and gas leases. The term "nontraditional" means that the methods differ from the historically prevalent cash-bonus bid, fixed-royalty-rate auction.

The nine nontraditional systems specified in the legislation are:

1. cash-bonus bid with diminishing royalty rate;

2. cash-bonus bid with fixed profit share; 
3. cash-bonus bid with both a fixed royalty rate and a fixed profit share;

4. royalty rate bid with a fixed cash bonus;

5. royalty rate bid with a fixed work commitment for exploration;

6. royalty rate bid with both a fixed work commitment and a fixed cash bonus;

7. profit share bid with a fixed cash bonus;

8. work-commitment bid with a fixed cash bonus and a sliding scale royalty rate;

9. work-commitment bid with a fixed cash bonus and a fixed royalty rate.

In 1979 a group of litigants, including the State of California (which receives a share of OCS revenues), the City of Long Beach, California (which has a stake in some nonfederal offshore oil lands), several consumer groups, and three private citizens began legal action to alter the mix of the alternative systems that the federal government had adopted. ${ }^{5}$ By 1981 the government had used nontraditional auctions on leases covering 49 percent of the total area offered, but this program had used only two of the nine alternatives, both involving a cash-bonus bid. The plaintiffs also sought an injunction barring further lease sales until the government promulgated new regulations for using all of the alternative auction mechanisms.

The court of appeals joined the district court in refusing to issue a series of injunctions against scheduled lease sales, but it ruled that the legislation required the Secretary of the Interior to experiment with some of the auctions not using the cash bonus as the bidding variable. ${ }^{6}$ The Secretary and others appealed, and the Supreme Court sided with the government, holding that, "[i]t is not for us, or for the Court of Appeals, to decide whether the Secretary of the Interior is well advised to forgo experimentation with the non-cash-bonus alternatives." 7

The Court's ruling turned in part on the narrow question of interpreting congressional language directing that twenty to sixty percent of leases were to be sold using nontraditional auctions. ${ }^{8}$ The government's aggregate usage of the various nontraditional auctions was clearly within those bounds, with nontraditional methods being used on 49 percent of the total area offered up to that time. Although the Secretary had chosen only those alternatives using a cash-bonus bid, the Court held that his action was within the legislation's requirements. Nevertheless, the Court's ruling did partly consider the economic and legal intentions of the Congress in passing the 1978 Amendments. And, it is Congress's economic intentions that we briefly review here.

In directing the Secretary to use the nontraditional methods on at least twenty percent of the tracts at auction, and in allowing their use on up to sixty percent of the tracts at auction, Congress was apparently asking that these systems be tried out, without committing the government to a complete abandonment of the cash-bonus bid, fixed-royalty 


\section{Supreme Court Economic Review}

system. Considering the legislation's extensive requirements for the executive branch to report to Congress on the new systems, we interpret this congressional action as a desire to compare the relative efficacy of the various bidding mechanisms in achieving some set of policy objectives. ${ }^{9}$

Both the legislation and the committee reports present a fairly consistent statement of congressional goals. ${ }^{10}$ In the legislation we find, among others, the following four purposes:

1. To make [OCS] resources available to meet the Nation's energy needs as rapidly as possible;

2. To balance orderly energy resource development with protection of the human, marine, and coastal environments;

3. To insure the public of a fair and equitable return on the resources of the Outer Continental Shelf;

4. To preserve and maintain free enterprise competition. ${ }^{11}$

In a later section, the legislation directs that "[l]easing activities shall be conducted to assure receipt of fair market value for the lands leased and the rights conveyed by the Federal Government."12

The Conference Report lists goals that should be taken into account, including but not limited to:

1. Providing a fair return to the Federal Government;

2. Increasing competition;

3. Assuring competent and safe operations;

4. Avoiding undue speculation;

5. Avoiding unnecessary delays in exploration, development, and production;

6. Discovering and recovering oil and gas;

7. Developing new oil and gas resources in an efficient and timely manner;

8. Limiting administrative burdens on government and industry. ${ }^{13}$

Even though many of the words used in these objectives are familiar to economists, evaluating the bidding processes in their light presents two difficulties. First, operationalizing their meaning in the context of OCS leasing must be as precise and unambiguous as possible. Second, even if the implications of the bidding processes are clear, there may be inconsistencies in the goals, which generate a consideration of policy trade-offs.

To illustrate these problems, let us consider in some detail the objective that appears repeatedly throughout the Court's decision, the gaining of "fair market value" for the leases. ${ }^{14}$ That phrase, or some variant of it, is issued at least nineteen times in the text and footnotes of the Court's decision. But, what does it mean?

First, there is some ambiguity in the legislation regarding the definition of the commodity for which the government is to obtain a "fair market value." The obvious answer is "a mineral lease" with a "fair market value" defined at the time of the lease's sale. This is an obvious answer, because the government is explicitly not in the business of pro- 
ducing and recovering its own oil, even though it may retain a royalty right. Instead, what the federal government is selling is the right to extract and sell oil and gas from government-owned property. As the Act states, it is this lease and the "rights conveyed" that Congress desires to be sold at a "fair market value."15 The use of the term "market" value confirms the interest in the value at the time that the government markets the commodity, the lease. This is what economists would call the valuation of the tract ex ante its development, that is, before the revelation of the true value of the uncertain variables in the economic calculation, such as the future price of oil and gas, the tract's geological productivity, and so forth. The ex ante point of view finds this uncertainty reflected in the lease's "fair market value."

The "Definitions" section" of the legislation is not very helpful in pinning down Congress's use of the term "fair market value," for the term is defined only in the context of the minerals produced from the lease after that production has actually occurred:

The term "fair market value" means the value of any mineral . . . computed at a unit price equivalent to the average unit price at which such mineral was sold pursuant to a lease during the period for which any royalty or net profit share is accrued or reserved to the United States pursuant to such lease . . . .17

Economists call this value the expost average valuation of the minerals. Of course, there will be a connection between the expected ex post value of the minerals and the ex ante value of the lease, although other variables, such as the rules of the lease, will also affect value. But, the "fair value" of the lease at the time that it is marketed is distinct from the ex post realization of the unknown variables. This distinction occurs in the same way that a house sold in 1950 had a well-defined fair market value for 1950, regardless of its value in 1983 .

Indeed, a generous interpretation of congressional intent, based on the Conference Report's discussion of the definitions, ${ }^{18}$ is that the legislators never intended this ex post language to apply to that part of the Act concerning leases, ${ }^{19}$ but only to other sections of the legislation discussing the downstream marketing of the oil and gas products. ${ }^{20}$ Other parts of the same Conference Report seem more ambiguous.

We remain unconvinced that one can rule out completely that Congress was operating with a picture of the "fair market value" of government OCS leases that was related to the actual expost realized value of the minerals. ${ }^{21}$ Nevertheless, whichever interpretation of congressional intent in the "definitions" section of the Amendments is correct really makes very little difference for the discussion here. The government can be assured of obtaining the equivalent of the ex post average price of the oil and gas only if it retains ownership of all of the minerals, and consequently, of all of the geological risk and the risk of oil- and gas-price fluctuations. This retention of rights is inconsistent with the idea of the leasing of government properties. Therefore, we assume that it is the ex 


\section{Supreme Court Economic Review}

ante fair market value of the lease that interests Congress. The next step is to pin down the word "fair."

In at least seven of the nineteen instances in which the Court uses the term "fair market value" or some similar phrase, it is in conjunction with some reference to the term "competition." 22 This conjunction raises the question of whether Congress and the courts view the "fair market value" of a lease as the price that would obtain in a perfectly competitive market for leases. Such a linkage would be paradoxical, because a striking feature of the market for OCS leases is that the federal government dominates in the control of the remaining domestic sources of potential oil- and gas-bearing lands, with all of the attendant powers to limit quantities, to increase the returns that accompany this power. ${ }^{23}$ We seriously doubt that the Congress wishes the Secretary to act as though he is ignorant of the government's selling power. One should restrict attention to models of the market for leases that reflect this reality. Therefore, we view the market for leases as a series of perhaps simultaneous auctions for a single, indivisible unit of a unique commodity, with the seller determining the number and timing of such sales.

There is substantial evidence to suggest that the intent of Congress is to equate "fair market value" with "greatest possible expected revenue." The House Report explicitly uses the phrase "higher returns to the public Treasury." 24 The standing granted the State of California in Energy Action is based in part on the claim of injury to California should the auctions not produce a "fair market value," 25 because by statute that value is shared with California. Of course, we find no evidence in the Court's decision of California articulating a notion of any harm that would befall it should the auctions yield it an "unfairly" large amount of money.

If the preceding interpretation of "fair market value" is correct, then the nature of the issue in this "experiment" is thus. Each of the bidding-lease systems will cause each firm to calculate its most advantageous bid. Inter alia, this bid will depend on how many firms are bidding, what the firm expects other firms to do, what it believes about the uncertain future variables, and what the firm sees as its optimal pattern of development if it wins the auction and must pay some bonus, royalty, profit share, or work commitment according to the auction's rules. The same set of variables, as reflected in each firm's bid, yields the federal government at the completion of the auction a discounted stream of expected returns, $V$. This $V$ is composed of some combination of a cash bonus, royalty, or profit share, depending on the auction's rules. The question that Congress seems to be asking is, "which of the endorsed bidding schemes generates the highest total of $V \mathrm{~s}$ across the tracts expected to be auctioned off?"

Notice that $V$ will depend greatly on the production plan that the lease's terms induce the auction winner to adopt. As Section II explains, the lease's downstream payment terms affect the winning firm's develop- 
ment plans. ${ }^{26}$ Therefore, suppose that for a given production schedule, a particular winning royalty bid, and a particular winning bonus bid, a cash-bonus-bid auction and a royalty-rate bid auction apparently yield the same values of $V$. We cannot assert that the two lease rules in general will return the same level of $V$ to the government, because they will commonly induce different production patterns.

There are other possible interpretations of "fair market value." An alternative to the "highest-revenue-generating" criterion just discussed would be to require that the auction be fully "demand revealing." An auction is demand revealing if each firm's bid fully represents the maximum amount that it would be willing to pay, given the rules of the lease. Combined with the congressional directive that the lease be awarded to the highest bidder, a demand-revealing auction has two important implications. First, the lease will be awarded to the firm that values it the most, which means that the lease allocation is efficient. Second, the winning bid correctly reveals to the government the maximum that any bidding firm is willing to pay for the lease.

If demand revelation is the intent of Congress in seeking "fair market value," then the menu of congressionally endorsed auction processes leaves much to be desired, because all of the alternative procedures are being operationalized as "first-price," sealed-bid auctions, those in which the lease is awarded to the highest bidding firm, which pays the amount that it bid. A well-known property of such auctions under conditions of uncertainty is that they are not demand-revealing. ${ }^{27}$ The winning bid in such auctions generally will not reflect the maximum willingness to pay among the bidders. Section IV contains discussion of the kinds of auctions that can be demand-revealing and of the properties of such auctions. ${ }^{28}$

A fourth possible interpretation of "fair market value" is a sales price that just exhausts all of the potential willingness to pay of the losing bidders. To demonstrate the implications of this requirement, suppose that it does not hold. Then, at the moment of the auction's completion, there exists at least one losing bidder who, at the limit, would be willing to purchase the lease from the winner at a price greater than what the winner paid to the original seller. Therefore, in a sense the winner would have expropriated some residual value from the government.

For example, suppose that a first-price auction (an auction in which the winner pays what he bids) is held in which the highest private valuation of the object among losing bidders is $\$ 10$. If the winning bid were less than $\$ 10$, then the "high-value" losing bidder has a limit-demand price greater than the price that the original seller received. Thus, $\$ 10$ is the knife-edge value that just exhausts the value of all losing bidders. Whether the auction's winner potentially would be willing to resell at the highest losing bidder's limit-demand price depends on his own valuation. If it is greater than $\$ 10$, then he would not. If it is less than $\$ 10$, then he would. Notice that an auction in which the winning bid does not exhaust 


\section{Supreme Court Economic Review}

the willingness to pay of all losing bidders has two problems. Not only may the object be sold to one bidder for less than its opportunity cost (in this example, $\$ 10$ ), but also such an auction allows the object possibly to be awarded initially inefficiently (that is, to a bidder who does not value it the most). As Section IV explains, there exist auctions that obtain this concept of "fair market value" and that are not first-price auctions. ${ }^{29}$

There may be trade-offs between any one of these concepts of "fair market value" and any of the other congressional goals. For example, overly rapid production from an oil field can damage the geological structure's internal drives. Thus, making resources available "as rapidly as possible" may not be "efficient and timely," nor may it yield the government's maximum expected return.

\section{B. The Benchmark Auction Process}

Before examining economic implications of the nontraditional auctions, consider the following benchmark. Both the respondents and the Court in Energy Action emphasize that a common feature that distinguishes the nontraditional mechanisms that the Secretary had employed is the use of a cash bonus as the bidding variable. The respondents believed cash-bonus bidding to be an inherently undesirable feature. ${ }^{30}$ Let us consider the polar extreme case of auctions with such a feature: the first-price, pure cash-bonus-bid auction, with no subsequent royalty, rental, or profit share. Although it is not on the list of congressionally approved auctions, the first-price, pure bonus-bid auction can serve as a useful reference point, highlighting the implications of an auction that come from the features of the first-price-award rule of bonus bidding.

Economists have extensively studied the first-price, pure bonus-bid auction. ${ }^{31}$ An important component of any model of auction decision making is the description of what the bidders know about the object at auction and about each other. This component is called the "information structure." Several different information structures have been examined, the most relevant to this discussion being the so-called "mineral-rights" structure. ${ }^{32}$ In the mineral-rights structure, the object at auction, in this case, an OCS lease, has an unknown value, $x$, to any winning bidder. This value is revealed as the field is developed. Each bidder (firm) knows some public (common-knowledge) information about $x$ and enjoys some private information or signal about $x$, called $s_{i}$. All firms know that each firm's $s_{i}$ is drawn independently from a distribution relating signals to the true tract value, $x$. No firm knows any other firm's $s_{i}$.

There are four important aspects of the first-price, pure cash-bonusbid auction in the mineral-rights information structure. First, the auction generally is not demand-revealing. Each firm commonly has an incentive to bid less than its maximum willingness to pay. This property derives from the first-price nature of the auction and the information structure, and it does not require that the cash bonus be the bidding variable. ${ }^{33}$

Second, the relationship between the number of firms submitting 
bids and the winning bid is much more complex than the hypothesized connection implicit in much of the congressional commentary. The connection between "increased competition" and "higher returns" 34 suggests that Congress conceived of a very simple relationship between the observed number of bidders and the government's receipts, with more "competition," a larger number of firms bidding, yielding higher "returns." In some cases a given firm's most advantageous bid will increase as the number of bidders increases. But, in other cases it falls. Nevertheless, under fairly general conditions the winning bid gets very close to the true value of $x$ as the number of bidders gets very large. Again, this phenomenon is a function of the first-price auction rules and the information structure, and its analog could also be observed with bidding variables other than the cash bonus. ${ }^{35}$

Third, the winning bidder in this idealized benchmark auction views his payment to the government, the cash bonus, as a sunk cost in developing the tract. ${ }^{36}$ This treatment of the bonus induces an efficient development program for the tract. This is a feature of the pure cash-bonus nature of the payment, and it would hold in other than first-price, sealedbid auctions.

Fourth, all of the development risk falls on the winning bidder and none of it on the government. This also is a feature of the pure cashbonus payment, and it would hold in other than first-price, sealed-bid auctions.

These four aspects of the benchmark auction process provide a useful comparison with the realities of the ten congressionally authorized bidding systems. A final caution to be kept in mind is that virtually all theoretical studies involve a common simplifying assumption, namely that each tract generates a demand schedule that is independent of the outcomes of auctions of other tracts. In reality, each OCS-lease sale consists of simultaneous auctions of several tracts. Because a bidder may view the tracts as substitutes or complements for one another, his willingness to pay for one tract may not be independent of the auction outcome on the other tracts. In that case, the bidder faces a more difficult combinatorial problem than is usually modeled. ${ }^{37}$

\section{PROPERTIES OF AUCTIONS AUTHORIZED BY THE 1978 AMENDMENTS}

All of the auctions that the 1978 Amendments authorized are firstprice or highest-rate auctions. Therefore, they all share the common generic incentive property of such auctions: each bidder has an incentive to under-reveal his demand, that is, to submit a bid such that the expected present discounted value of his total up-front and downstream lease payments is less than he thinks that the lease is worth when he submits his bid. Although all of these auctions share the under-revelation property, they do not necessarily share it equally. Thus, some of the authorized 
auctions may provide bidders with quantitatively more significant underrevelation incentives than do others. But, the theoretical and empirical research that would be required to discern the comparative quantitative properties of these auctions has not been done.

A second incentive property of these auctions is interrelated with, but distinct from, the demand under-revelation incentive; it is the nature of the exploration and development incentives for a winning bidder contained in a lease's downstream-payment terms. We discuss these incentive properties here.

Before passage of the 1978 Amendments, royalty rates were often set at $12 \frac{1}{2}$ or $16 \% / 3$ percent, which led to highest-bonus bids submitted in the traditional auction that varied between zero, on tracts that drew no bids, and several hundred-million dollars. Presumably, the zero-bid tracts were ones about which little was known or for which the available information was unfavorable. Each of the tracts that drew large bonus bids was obviously thought to be quite valuable by at least one bidder. Much attention has been focused on the very large winning bonus bids and the implications of the size of the bonuses for the number of qualified bidding entities capable of bearing risks of that magnitude. It is commonly argued that only a few of the largest oil companies can bear risks on individual tracts of the size implied by many winning bids and that smaller qualified bidders are individually excluded and able to compete only if they can combine into joint bidding syndicates. The result is a relatively small number of bidders, on the order of three per leased tract. This outcome has been interpreted as a lack of "competition" for the leases, which is alleged to reduce public revenues from lease sales and to lead to increased concentration in OCS oil and gas production.

The congressional committee reports express the hope that, relative to use of the traditional auction, the adoption of some of the newly authorized auctions would lead to a substitution of downstream payments for up-front payments on leases. The rationale for seeking such a substitution apparently was a belief that lower bonuses and higher downstream payments would increase the number of bidding entities in serious contention for leases and that this increase would enhance total lease revenues and diminish concentration in OCS oil and gas production. But, professional research does not fully support these beliefs. For example, the alleged positive relationship between lease sales revenues and the number of bidders has been challenged. ${ }^{38}$ But, since increasing the number of bidding entities by diminishing up-front lease payments was a rationale for requiring the use of alternative auctions in the 1978 Amendments, we now compare auctions in these terms.

\section{A. Authorized Cash-Bonus-Bid Auctions}

The 1978 Amendments authorize four cash-bonus-bid auctions. One such auction is the fixed-royalty-rate, cash-bonus-bid auction that was used to auction most OCS leases in earlier years. The other author- 
ized bonus-bid auctions differ from the familiar one in the way in which the contingent downstream payments are calculated. The three alternative downstream-payment terms are: (1) diminishing or sliding-scale royalty rate, beginning at a rate not less than $12 \frac{1}{2}$ percent; (2) fixed share of net profits, not less than thirty percent; and (3) fixed-royalty rate, not less than $12 \frac{1}{2}$ percent and fixed share of net profits, not less than thirty percent.

The Department of Energy (hereinafter DOE) issued final regulations for the fixed-and sliding-scale royalty-rate auctions that have these provisions. ${ }^{39}$ One auction has a cash-bonus bid, a fixed-royalty rate, and an annual rental payment for each leased tract. The other auction has a cash-bonus bid, an annual rental, and a diminishing or sliding royalty rate of not less than $121 / 2$ percent at the beginning of the lease period. The royalty-rate schedule determines the applicable royalty rate from the "adjusted" value of production, with the "adjustment" based on the GNP fixed-weight price index. ${ }^{40}$ The applicable royalty rate is then applied to the actual value of production to determine the royalty payment.

DOE issued final regulations for the cash-bonus-bid auction that provide for downstream-lease payments based on a fixed share of net profits, not less than thirty percent, and an annual rental.41 The profitshare rate is applied only after "capital recovery" by the lessee in the amount of expenses incurred for specified exploration and development activities plus a "reasonable" return on the investment represented by those expenses. ${ }^{42}$

\section{B. Authorized Royalty-Rate-Bid Auctions}

The 1978 Amendments authorize three royalty-rate-bid auctions. They differ from each other in terms of the up-front lease payments for which a winning bidder is liable. The three alternative up-front payment terms are: (1) fixed-dollar work commitment; (2) fixed-cash bonus; and (3) fixed-cash bonus and fixed-dollar work commitment. DOE issued final regulations for a royalty-rate-bid auction with a fixed-cash bonus and an annual rental. ${ }^{43} \mathrm{~A}$ winning bidder in this auction is responsible for royalty payments based on the constant royalty rate specified in his (highest) royalty-rate bid.

\section{Authorized Profit-Share-Bid Auction}

The 1978 Amendments authorize one profit-share-bid auction. The up-front payment term of this auction is a fixed-cash bonus. DOE issued final regulations for an auction with a net-profit-share-bid variable, a fixed-cash bonus, and an annual rental payment for each tract. ${ }^{44}$ In this auction, a winning bidder is responsible for up-front payment of the fixed-cash bonus. The downstream payments based on the profit-share bid are calculated thus. Before payment of any net-profit share to the government, a lessee can recover specified exploration and development expenses, plus a "reasonable" return on the investment represented by those expenses. Following this "capital recovery," the lessee is liable for 
payment of a share of net profits from production and sales equal to the highest profit share bid in the auction. ${ }^{45}$

\section{Authorized Dollar Work-Commitment-Bid Auctions}

The 1978 Amendments authorize two dollar-work-commitment-bid auctions. Both auctions have a fixed cash-bonus, up-front-payment liability for a winning bidder. The auctions differ in the method of calculating downstream payments in that one has a fixed-royalty rate and the other has a diminishing- or sliding-royalty rate, beginning at a rate of not less than $12 \frac{1}{2}$ percent. DOE issued final regulations for an auction with a dollar-work-commitment-bid variable, a fixed-cash bonus, a fixed-royalty rate, and an annual rental payment for each tract. ${ }^{46}$ In this auction, a winning bidder is responsible for up-front payment of the fixed-cash bonus and for the amount of his work-commitment bid, to be paid either in cash or as a performance bond. The winner can satisfy the dollar-work commitment and recoup the cash payment or bond by conducting qualifying exploration activities. He may apply fifty percent of the allowable expenditures on such activities in satisfaction of the work-commitment bid.

\section{E. Properties of the Cash-Bonus Bid, Fixed-Royalty-Rate Auction}

The cash-bonus bid, fixed-royalty-rate auction has been used to sell most OCS leases to date. Under the OCS Lands Act, ${ }^{47}$ and under the 1978 Amendments, 48 the royalty rate used in any particular lease sale must be not less than $121 / 2$ percent. Setting the royalty rate affects both the timing of lease payments and their cumulative total. Ceteris paribus, the higher (lower) is the royalty rate the lower (higher) is the bonus bid that any bidder will make on a lease. Thus, in specifying the royalty rate, the Secretary is determining a division of total lease payments between upfront bonus and downstream contingent payments. But, the cumulative total payment on a lease also can vary with the royalty rate. The reason for this variation is the royalty rate's exploration and development incentive effect on a winning bidder. In addition, since the royalty rate affects the division of lease payments between a certain front-end bonus and contingent royalty payments, it affects the allocation of the risk borne on the leased tract between the private lease buyer and the public lease seller. ${ }^{49}$ In other words, since a higher royalty rate leads to a lower lease bonus, the higher rate causes a substitution of risky contingent-royalty payments for certain lease-bonus payments; hence, the higher rate shifts risk from the lease buyer to the lease seller.

Clearly, by choosing a royalty rate that is considerably higher than the traditional rates, the government could substantially reduce the average size of winning bonus bids. Such a reduction would make it possible for a larger number of qualified bidders to bear the risk of the up-front bonus. But, high royalty rates create undesirable incentives for the exploration and development of leased tracts. The reason for these effects is that before income tax the lessee must pay 100 percent of the explora- 
tion and development cost, but he only receives that 100 percent minus the royalty percentage rate of the oil produced. For example, if the royalty rate is $66^{2 / 3}$ percent, then to have an incentive to incur the expense, a lessee would have to expect a present discounted value of at least $\$ 3$ of oil production to result from an additional $\$ 1$ of exploration and development expense. By implication, very high royalty rates would lead to some otherwise promising tracts not being efficiently developed. Therefore, trying to increase the number of competing bidders by setting high royalty rates in the traditional auction would lead to less efficient tract development and probably less production on OCS tracts. The risk-allocation and exploration-development incentive implications of the royalty rate are thus central to an evaluation of the traditional OCSlease auction and provide useful criteria for comparing the traditional auction to the other auctions authorized in the 1978 Amendments.

F. Comparison of the Newly Authorized Bonus-Bid Auctions with the FixedRoyalty-Rate, Bonus-Bid Auction

How do the newly authorized bonus-bid auctions compare with the traditional auction in terms of risk allocation and exploration and development incentives? First, consider the net-profit-share auction. As set out in the applicable DOE regulations, a lessee would be allowed (capital) recovery of allocable exploration and development expenses, plus a "reasonable" return on those expenses, before beginning profit-share payments on the lease. The lion's share of exploration and development expenses are the costs of drilling and equipping wells. Furthermore, even the largest oil companies usually contract out drilling on OCS leases to specialized companies. Hence, the capital-cost deduction in contemplation of law under a net-profit-share lease should correspond closely to the actual economic (capital) costs of exploring and developing leases. But, these investment costs, plus a "reasonable" return on the costs, are deductible from (production-sales) revenue before any net profit-share payment liability is incurred. Therefore, on leases acquired under the net profit-share auction, a (risk-neutral) lessee will have an incentive to make all exploration and development investment expenditures that yield expected revenue with a present discounted value that exceeds the investment cost. Hence, the downstream-payment terms of leases sold under the net profit-share auction would not have the severe exploration and development disincentives of the traditional auction with high royalty rates.

The net profit-share variant of the bonus-bid auction thus appears superior to the traditional auction for reducing bonus bids by increasing expected downstream payments on leases. Setting relatively high profitsharing rates will lead to relatively low winning bonus bids. This reduction in the magnitude of bonus bids will increase the number of bidders able to bear the risk of the up-front bonus, by transferring part of the risk to the government in the form of contingent profit-share payments; hence, the number of bidders in the auction should expand. 


\section{Supreme Court Economic Review}

A further consideration in comparing these two auctions concerns enforcement and compliance costs. To comply with DOE regulations on leases sold under the new auction, lessees must adopt the new accounting scheme. ${ }^{50}$ In addition, the United States Geological Survey (hereinafter USGS) will be required to audit the new net-profit accounts.

Next, consider the diminishing royalty-rate variant of the bonus-bid auction. A relatively high royalty-rate schedule will substitute downstream payments for up-front bonus payments on a lease, and therefore it should increase the number of auction bidders. But, as with relatively high fixed royalty rates (horizontal schedules), relatively high sliding royalty-rate schedules imply a severe disincentive for exploration and development activity. In deciding whether further exploration and development is worthwhile, a lessee will be concerned with the expected present discounted value of royalty payments. If those payments are a large proportion of the expected present discounted value of the increase in production that would result from the increased investment, then the investment may not occur. It makes little difference to this analysis whether a high average royalty rate results from a horizontal or a decreasing rate schedule.

A decreasing royalty-rate schedule can have an advantage for prolonging production from depleted fields with high average production costs. After a fully developed lease has been in production for many years, the natural drive of the reservoir, and therefore the production rate, declines. But, yearly production costs do not decrease as rapidly as does yearly production. Indeed, yearly production costs can increase. Therefore, average production cost increases. As soon as average production cost exceeds the average value of production times one minus the royalty rate, it will no longer pay to continue production on the lease. Production can be prolonged if the royalty rate decreases sufficiently, and certainly, if it decreases to zero. ${ }^{51}$

\section{G. Comparison of Royalty-Bid Auctions with Bonus-Bid Auctions}

In a royalty-bid auction, USGS would set the up-front payment terms of a lease, and the downstream payments, other than lease rental, would depend on the winning royalty-rate bid. First, consider the auction in which the up-front payment is a fixed cash bonus set by USGS. Ceteris paribus, a high bonus will lead to low royalty bids and vice versa. But, if high bonuses are a problem, it matters little whether they are set by the lessor or determined by bid. Furthermore, if high royalty rates lead to inefficiency in exploration and development, it also matters little whether the high royalty rates are set by the lessor or determined by bid. Thus, the royalty-bid, cash-bonus auction does not appear to promote the objectives set out in the 1978 Amendments.

The variant of the royalty-bid auction with a fixed-dollar work commitment has somewhat different properties than the cash-bonus variant of this auction. To date, the DOE has not issued regulations for this 
auction. But, if such regulations are forthcoming, then a fixed-dollar work commitment will share many of the features of the work-commitment-bid auction. Specifically, assume that a lessee could recoup a fixed-dollar work-commitment payment or performance bond by a fifty-percent credit on allowable exploration expenses, as in the work-commitment-bid auction. This credit would provide a fifty-percent subsidy to incremental exploration expenditures as long as the work commitment had not been met. This incentive would interact with the incentive for under-investment in exploration and development inherent in a positive royalty rate. But, the USGS would not have the necessary information to allow it to fine-tune these offsetting incentive effects for exploration, to achieve lease-payment terms that promote efficiency in exploration. The workcommitment variant of the royalty-bid auction would thus appear to have less severe exploration disincentive effects than would the cash-bonus variant. But, the cash-bonus-bid, net-profit-share auction appears to dominate both of these auctions in promoting efficiency in exploration and development.

\section{H. Comparison of the Profit-Share-Bid Auction, with Bonus-Bid Auctions}

The profit-share-bid, fixed-cash-bonus auction can have the same advantage as the cash-bonus-bid, fixed-profit-share auction just discussed: a relatively low up-front bonus can be combined with relatively high downstream payments, without severe exploration and development disincentives. Therefore, the preceding comparisons of the bonusbid, net-profit-share auction to other auctions can apply to the profitshare-bid auction. There is one possible problem with the profit-share bid, fixed-bonus auction that is not shared by the bonus-bid, fixed-profitshare auction. That is the possible incentive for premature lease abandonment by capacity-constrained firms facing very high, bid-determined profit-sharing rates. USGS can guard against this outcome by not setting very low fixed bonuses.

I. Comparison of Dollar-Work-Commitment-Bid, Auctions with Bonus-Bid Auctions

The dollar-work-commitment-bid auction has some interrelated, unusual properties for both lease-value determination and for efficiency in exploration. The efficiency implications follow from the fifty-percent credit for qualifying exploration expenses toward recouping the workcommitment cash payment or performance bond. As long as the workcommitment bid has not been fulfilled, the fifty-percent credit provides an incentive, a subsidy, for overinvestment in qualifying exploration activities. This incentive interacts with the incentive for underinvestment in exploration and development inherent in a positive royalty rate. The net effect of these provisions is a disincentive to development and an incentive for exploration of generally indeterminate direction and size. 


\section{Supreme Court Economic Review}

The lease-valuation properties of this auction are confused with its implicit subsidy to exploration. If the fixed bonus, royalty rate, and rental terms of a lease are sufficiently low, then a bidder has an incentive to calculate his work-commitment bid as if it were a partially rebatable bonus bid. In that case this auction, in effect, becomes a bonus-bid, fixed-royalty-rate auction with an implicit subsidy to exploration. Alternatively, if the lease's fixed terms are sufficiently high, then a bidder has an incentive simply to bid fifty-percent of his expected subsidized expenditure on qualifying exploration activities. In that case, this auction does not provide a market-determined value for the lease.

The preceding discussion reveals that elementary economic theory can provide some insights into the properties of the authorized auctions. But, we cannot resolve in this way some of the questions that the legislation posed. In particular, the concern with the relative revenue-generating properties of the auctions presents some challenging questions for theoretical and empirical research.

\section{THE EXPERIMENTAL COMPARISON OF AUCTIONS}

We have loosely referred to the congressional directive for using nontraditional auctions as an "experiment." This terminology also appears in the Court's decision. ${ }^{52}$ In its broadest sense, the term "experiment" could mean "investigation," encompassing both theoretical and empirical analysis.

The previous section demonstrates that economic theory can answer some of the questions implicit in the legislation and its congressional history. But, theoretical analysis in the absence of empirical testing is of limited and questionable value. As Section II suggests, some of the questions that Congress is asking are in advance of the current state of theoretical knowledge. Some of the results are qualitative, and if an auction displays mutually countervailing qualitative incentives, then the net theoretical prediction can be ambiguous. And, just because a wellformed theory exists does not imply that the theory has passed the test of yielding valid predictions.

Theoretical and field or laboratory experimental analyses are complementary. The judicious use of theory can guide the experimenter in discerning which are the most important tests. By demonstrating that one or more of the auction mechanisms creates undesirable incentives, theoretical analysis can winnow out the promising auction mechanisms for further empirical tests. ${ }^{53}$ Results of empirical studies also may provide insights for extending the state of theoretical knowledge. In this way, theory and experiment synergistically interact.

Likewise, field and laboratory observations can complement each other and economic theory. ${ }^{54}$ Nevertheless, there are important methodological differences between these two empirical approaches. We argue here that the field-experiment approach that the 1978 Amend- 
ments implicitly endorsed harbors many methodological shortcomings. We then examine the relatively new technique of laboratory experiments, which is potentially superior to field tests in answering questions that Congress asked in the 1978 Amendments.

\section{A. The Congressional Directive as a Field Experiment}

In the 1978 Amendments, Congress directed that the nontraditional auctions account for at least twenty percent of the total number of auctions. ${ }^{55}$ The Amendments also include extensive requirements for the Secretary to report to Congress on the results of the various auctions. ${ }^{56}$ These requirements add up to asking the Secretary to conduct a field experiment.

In the argot of experimentation, the primary "treatment variable" in the experiment is the legal-institutional environment, defined by the auction rules and the lease's downstream features. But, there are other variables less under the Secretary's control that could affect the bidding firms' decisions. Some of these variables relate to the geological and economic environment, for example, to the geological structure under the tracts, the implications of seismic or other surveys, the present and expected future prices of oil and gas, and so forth. We use the phrase "geonomic variables" to identify this category of variables. Another category includes those variables that relate to the motivational and decisionmaking attributes of the specific firms in the bidding. We call these "bidder-specific" variables.

A primary requirement for a valid experiment is that the geonomic and bidder-specific variables remain constant while the institution is altered. In field experiments, in which complete control usually is not possible, that control could be approximated if the geonomic and bidderspecific variables were randomized and unbiased in their occurrence among the different auction institutions.

Perhaps because of the guidance of the received theory, we might also believe that the auctions' relative performances will depend on the realized values of the geonomic variables, as the auction institution is perturbed. If this proposition requires tests at different realizations of the geonomic variables, at least one of two conditions must hold: first, the geonomic variables must be experimenter controlled and alterable; or second, the geonomic variables are not experimenter controlled, but they must occur at the "appropriate" values randomly and unbiasedly across the other treatments. Of course, in either case the experimenter should know the pattern of the geonomic variables, to associate their realization with the performance of the auctions. Finally, after collecting all of the relevant data under all of the appropriate experimental conditions, the experimenter can compare the various institutions with reference to the exogenously determined policy objectives.

Compare this idealized field-experiment process with the attributes of the OCS field "experiment." First, there is little ability to control 
geonomic and bidder-specific conditions as the auction mechanism is varied. The only way that the government can perturb the auction institution is across the different OCS tracts. To begin to meet the conditions of unbiased randomness and to allow for appropriate statistical inference, the Secretary could take a block of perhaps several hundred tracts, assign them randomly among the different auction methods, and then conduct all of the auctions simultaneously. Aside from the possible contamination of the experiment from tract-value interdependencies, there is the problem of bidder self-selection biases across the different auction institutions. ${ }^{57}$

Second, the government also has very little ability to alter the geonomic variables to values that create the most powerful or critical tests. Even if the geonomic variables that prevail appear randomly across the treatments, some key realizations simply might not be observed in the field.

Third, there is a vast amount of uncertainty associated with any OCS auction. Not only are many of the geonomic variables usually unknown, but also the government probably knows little about variations in bidder expectations regarding these variables. Similarly, the government might know little about variations in the bidder-specific variables across auction participants.

Fourth, to the extent that Congress desires an ex post evaluation of its objectives, the appropriate data could take decades to collect. For example, to compare the revenue-generating properties of different auctions using field data, the experimenter would have to wait until data on downstream lease payments were available.

Finally, for the experiment to be valid, every experimental sample requires a binding commitment to lease an OCS tract under the proposed rules. The field experiment may demonstrate that one of the approved auction processes results in disastrous agreements, but only at the expense of obligating the government to precisely such agreements on one or several OCS tracts. The Secretary might exercise statutory discretion to refuse to issue tracts from mechanisms discovered to be unsatisfactory and to rerun the auction with a different mechanism. But, the widespread expectation that this ex post change in rules might occur would alter bidder decisions in the first auction, rendering the resulting observations misleading or useless.

Hence, although the government collects a large amount of data from OCS auctions, what it can learn in the scientific sense from these observations is severely limited. Given some of the attributes of OCS auctions, we can easily illustrate the potential pitfalls of field experimentation. Suppose that, from a large body of field data from OCS auctions, one wanted to compare auctions $A$ and $B$. For the comparison to be valid, processes $A$ and $B$ should each have been tested unbiasedly across all of the relevant combinations of geonomic variables. But, if auction $A$ was used exclusively in $1979-1980$, while process $B$ was tested exclusively in 
1983, then a valid comparison seems impossible, because of the great difference in oil-market conditions in the two periods. Or, suppose that both were offered together in a relatively comparable time frame. Then, the expectations about underlying geological characteristics should have been randomly and unbiasedly distributed between the tracts offered under auctions $A$ and $B$. And, if the two kinds of auction processes were indeed tested in the same time period, this simultaneity creates a real possibility of self-selection bias in the observations. Although none of these potential shortcomings necessarily must materialize, we use them to emphasize the problems of interpreting OCS field data.

\section{B. An Alternative Experimental Technique}

The government might consider the use of laboratory-experimental methods as a supplement to field experimentation. This technique has already found use in many areas of economic research in general, and in the study of auction markets, in particular. We will not repeat here in detail the history of this technique's methodological grounding. Instead, we refer the reader to other work on this subject, ${ }^{58}$ and we list briefly some of the potential advantages of the laboratory technique. Section IV examines some of the existing experimental results on the performance of auction markets and discusses how they relate to the questions raised by the 1978 Amendments and by Energy Action.

The first and principal advantage of laboratory experimentation is in the control provided over the test's parameters. Perturbing the bidding rules and institutions is straightforward, and it can be accomplished in a relatively short time. The experimenter also has knowledge of and control over the experiment's features that are homologous to the geonomic conditions of an OCS auction. As an example, we could design an experiment so that the bidders are uncertain of the auctioned object's value and yet the experimenter can know and alter the information on which bidders base their estimate of that value. We can also alter the noninstitutional variables, such as individual values for the auctioned items, so that we can compare the bidding institutions at several reference points. ${ }^{59}$

A second advantage of laboratory experiments is that we can conduct informative tests of the different bidding institutions with values of the geonomic conditions that have never been observed in the field. We can create these conditions in the laboratory.

A third advantage of laboratory experimentation is that the direct resource cost is low, as is the opportunity cost of discovering the malperformance of one of the auction mechanisms. One of the processes might fail, but we have wasted no OCS tracts to find that out.

Finally, replication under controlled conditions is easy, and data collection is relatively quick. Both field and laboratory experiments have the limitation that bidder-specific attributes, such as risk preferences and adaptation abilities, are relatively unobservable. But, the laboratory technique enjoys at least three advantages concerning this problem. First, 


\section{Supreme Court Economic Review}

replication to sense the robustness of the results to individual idiosyncracies is easier in the laboratory than in the field. Second, we can more truly randomize individual bidders among institutions in the laboratory, with a lower probability of self-selection biases. Third, in the laboratory there are some partial ways to control or test for the influence of bidder-specific attributes, such as risk aversion, even if those attributes are unobservable.

Laboratory experiments surely cannot answer all of the questions that one might ask. But, any interpretation of either field or laboratory data in terms of an underlying hypothesis about bidder decision making requires certain control conditions. Laboratory experiments can test alternative models with control conditions not realizable in the field. From the results of laboratory tests, one is in a better position to reject inappropriate models and to select the more promising model or models of bidder decision making for further use in assessing policy alternatives, or in designing better field experiments for auctioning OCS leases. Time requirements are relatively brief, and laboratory experiments, again, require no commitment of OCS tracts as a part of the tests.

We would not pretend to anticipate the outcome of a comprehensive laboratory experimental test of any or all of the alternative OCS auctions. Each contains features that have not yet been incorporated in laboratory experimental work. Nevertheless, there has been extensive experimental research into other similar kinds of auction mechanisms. Section IV describes the nature of this research. When appropriate it reports what the existing auction experiments tell us about what we know, and about what we can potentially learn in the laboratory, concerning the various kinds of OCS auctions.

\section{THE STANDARD AUCTIONS: THEORY AND PERFORMANCE}

Historically, a great variety of auction institutions has evolved for the sale of a single object, such as an antique or a painting, or multiple units of identical items, such as U.S. Treasury Bills or gold bars. When there are multiple units of nonidentical items, it is customary to auction individual items in some sequence, as in livestock auctions, or in assembled lots, as in the Netherlands' produce and flower auctions. The OCS auctions differ from all of these examples in that individual tracts in a given auction are not identical, although they may be close substitutes or complements, and separate simultaneous bids must be tendered for each tract that each bidder desires.

While this technical difference between OCS and standard auctions is a feature of consequence, there are several reasons why an analysis of some of the standard auction systems is of direct interest and relevance to OCS leasing. First, the standard auctions illustrate some of the rich variety of different institutional procedures available for use in OCS leasing, whether the bids are in cash, as a royalty percentage, or in other forms. Second, theoretical analysis of these different auction institutions 
suggests that the price and efficiency of an award reflect the kind of auction used. Third, experimental evidence demonstrates that the kind of auction used affects both price and efficiency. Fourth, when the results differ among the different standard auctions, it is because the auction rules affect bidding incentives. We expect these incentive differences to apply with equal force to OCS leasing.

Here, we provide a brief overview of those auction institutions, the "standard" auctions, for which theories of bidding have been articulated, and that have been subjected to a rigorous experimental examination. To date, there has been no experimental examination of auction institutions, or of the theory of such institutions, that have the distinguishing properties of OCS tracts, namely, simultaneous bidding on multiple nonidentical items, and item valuation based on the acquisition of costly information. In view of the growing use of experimental methods in the study of pricing institutions, future research is likely to address these properties of OCS tracts.

\section{A. Definitions of the Standard Auctions}

Although the literature distinguishes a great number of different auctions, there are only four primary kinds: The English and Dutch "oral" auctions, and the first- and second-price, sealed-bid auctions. ${ }^{60}$

English auctions. These are the most commonly known auctions in the United States. The process begins with the auctioneer soliciting an initial bid from the crowd of potential buyers, for some object that is offered for sale. Any announced bid, when recognized by the auctioneer, becomes the standing bid. Any new bid is admissible only if it is higher than the standing bid. The sequence of ascending bids, each displacing its predecessor, ends when the auctioneer cannot solicit a new higher bid, and the item is declared sold to the last bidder at a price equal to the amount that he bids. Bidders can easily preserve their anonymity by agreeing to a private signaling system with the auctioneer. In some auctions, the auctioneer actively solicits bids, while in others the auctioneer merely recognizes bids that are freely announced from the floor. Most public auctions of art, antiques, equipment, livestock, and household goods in the United States and Great Britain use the English method. It is probably the oldest auction system. Thus, Cassady notes that according to Herodotus the Babylonians auctioned marriageable women as early as 500 B.C., and the method of auction appears to have followed the ascending-bid procedure.$^{61}$ Roman auctions probably used the ascending-bid procedure, since the word auction derives from the latin root auctus, meaning "an increase." 62

Dutch auctions. In the Dutch-auction procedure, the price begins at a level considered to be higher than any buyer is willing to pay, and the auctioneer decreases it orally until the first buyer signals acceptance. The item is awarded to this buyer at the price standing at the time of acceptance. Produce and cut flowers are sold in the Netherlands by this proce- 


\section{Supreme Court Economic Review}

dure, and an electric clock whose hands rotate counterclockwise automatically displays the descending prices. The buyer wishing to accept the standing-offer price depresses a button that stops the clock. Although this procedure is less familiar in the United States than is the English auction, it is often encountered here in some form. In Boston, Filene's Basement is famous for marking down all clothing on a regular schedule. The schedule rules are displayed and well known to shoppers. The airlines have used a variant of the Dutch procedure when a flight is overbooked, to induce volunteers to relinquish seat claims. In this case, there is a single buyer and many potential sellers. Hence, the "Dutch price," representing a bid to buy rather than an offer to sell, must ascend. Although the exact procedure probably varies, one approach is to raise the bid until enough passengers accept to clear the flight of all overbooked seats, with all such passengers receiving the same compensation.

In multiple-unit Dutch auctions, buyers need not pay a common price. Thus, according to Cassady, "[o]rdinarily, the first bid is the only bid, although it is conceivable, if the amount taken is optional, that the balance of a lot would be sold by continuing the price downward." 63 In the case of heterogeneous items, such as the component tracts of an OCS auction block, one could use the Dutch auction, allowing the first successful bidder the option of selecting the tract desired at the first acceptance price. The offer price then could continue its descent until a second acceptance, with the second bidder selecting the tract desired, and so on, until all tracts are sold.

First-price auctions. This is the well-known and widely used procedure in which each bidder submits a written bid. All bids are opened at once, and the highest bidder is awarded the item at a price equal to the amount bid. Thus, the first, or highest bid determines the price. As noted earlier, this is the institution used in OCS bidding. In the OCS auctions, all of the bids and bidders on each tract are publicized, not just the winning bid. Practices vary concerning the post-auction announcement of bids. In some sealed-bid auctions only the winning bid is announced, and in some only the winning and second highest bids are made public. In the primary auction of U.S. Treasury bills, a multiple-unit, sealed-bid auction, only the highest and lowest accepted bids are announced, but the identity of the bidders is not made public.

Second-price auctions. These auctions proceed as under the first-price rules, except that the highest bidder wins and pays a price equal to the second-highest bid submitted. This procedure is rarely used in practice, but it has been of considerable interest in the economics literature on auctions, because of its incentive properties. ${ }^{64}$ The second-price auction was first defined and analyzed by Vickrey, ${ }^{65}$ and it is sometimes called the "Vickrey auction." In the London stamp auction, and also in some primary fish markets that use oral English auctions, buyers not present are allowed to submit book bids.

In book bidding, the award is made at one level, or price interval, 
above the floor bid or the second-highest book bid, whichever is larger. . . . If he [the auctioneer] gets no bid from the floor, the goods are knocked down to the highest book bidder at a price just above the offer of the second-highest bidder. ${ }^{66}$

This is exactly the procedure that Vickrey calls the "second-price" method, except for the modification of the use of a standard-bid advance interval.67 Cassady also describes a written-bid auction "utilized in certain market situations, permitting each bidder to submit two bids rather than one. His higher bid goes into effect only if his lower bid does not exceed the bids of competitors, but the award is made on the basis of the lower figure if it is higher than the highest bid of competitors." 68 "This scheme may include the second-price auction, and it may be quite old. ${ }^{69}$

\section{B. Auction-Market Theory}

The four basic auctions just defined have distinct information and incentive properties, and as a consequence, they may yield different prices or allocations. The example illustrated in Figure 1 facilitates our discussion of the theory of these auctions. There, we suppose that there are $\mathrm{N} \geqslant 2$ buyers willing to bid for a single, indivisible item that the seller offers at any positive price determined in the auction; that is, the seller specifies no reservation price.

Our analysis here adopts four primary assumptions. First, each buyer $i$ associates a known (to that buyer) cash value, $v_{i}$, with the item, such that $v_{i}$ is defined as the maximum amount that $i$ would be willing to pay for the item rather than lose it to another buyer. Second, if $i$ and $j$ are distinct persons, then the value, $v_{i}$, to any $i$ is independent of the value, $v_{j}$, to any $j$, in the sense that $v_{i}$ would not change if $i$ had knowledge of $v_{j}$, and vice versa, for any $i$ and $j$. In particular, this means that each person's maximum willingness to pay has no information value for any other person. Third, each $i$ has complete knowledge only of his own value, and not that of others. And, fourth, the cost of transacting-thinking, deciding, and bidding-is negligible for each person.

We note that the second assumption does not prevent individual valuations from being correlated or associated in other ways. For example, all values cah be "high" or "low" for some object relative to another object, yet remain independent in the sense of this assumption. The second assumption has important consequences for the analysis of auctions, and later we discuss the effect of relaxing it. ${ }^{70}$ This assumption is important for applications to OCS leasing, because differences in individual values may reflect differences in information, and therefore values may not be independent if some bidders would be unwilling to ignore these information differences. ${ }^{71} \mathrm{By}$ itself, the first assumption is relatively innocuous for the analysis of auctions. If the value of an item to a bidder is uncèrtain, then we need only suppose that the uncertain prospect has an equivalent cash-certain value, reflecting the degree to which that person discounts for uncertainty because of risk aversion. The third assump- 


\section{Supreme Court Economic Review}

tion is important and necessary, because all valuations are inherently private and subjective. Furthermore, people are not normally well-motivated to reveal credible information about their own valuations to other market participants.

For convenience of exposition, Figure 1 numbers the buyers, so that $v_{1}>v_{2}>\ldots>v_{k=1}>v_{k}$, and it also rules out tied values. We say that an auction is efficient (Pareto optimal) in allocation if it awards the item to the person who values it most highly (buyer 1, in Figure 1). As Section I explains, the essence of this definition is that an efficient allocation exhausts the gains from exchange..$^{72}$ If the item is awarded to any buyer except $l$, say, to 3 , then that buyer can resell the item to $l$ at a price (above $v_{3}$ but below $v_{1}$ ) that yields a monetary gain to both persons. Observe that, by this definition, efficiency is an attribute of an auction quite distinct from the price resulting from an auction. One auction method might yield a higher proportion of efficient allocations than a second, even though prices achieved using the second auction are higher than those achieved with the first. This is because efficiency depends on the buyer with value $v$, bidding high relative to the bids of other buyers, while the auction price depends on the absolute level of the highest bid. Obviously,

Figure 1.

Illustration of buyer valuations for single object.

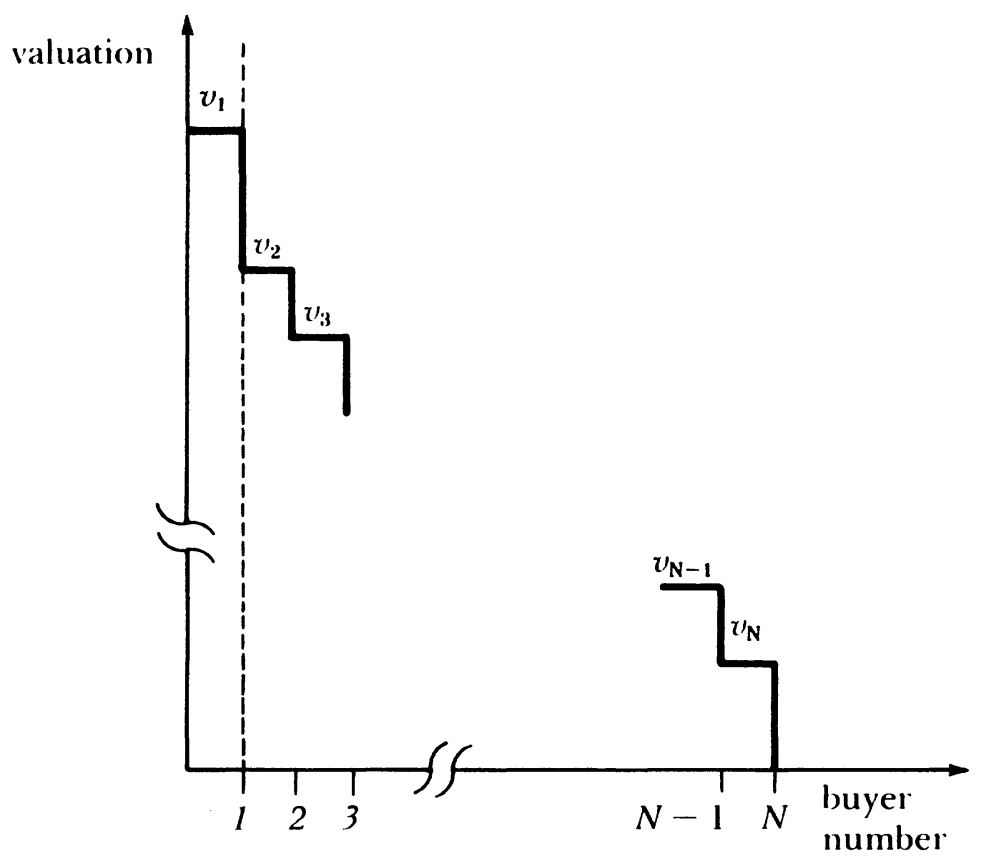


all bids might be quite low, but the award efficient, while all bids could be high, but the award inefficient. Consequently, a high price does not necessarily imply an efficient award, and the two attributes, price and efficiency, may be in conflict. ${ }^{73}$ Later, we provide experimental data demonstrating that this possibility is more than a mere abstract curiosity. ${ }^{74}$ But, from Figure 1 it is clearly possible for price to be such that the auction must be efficient; any price between $v_{2}$ and $v_{1}$, by the definition of $v_{i}$, must yield an efficient allocation.

Since, in any given market, the $v_{i}$ are not observable, the only evidence that may suggest inefficiency is the occurrence of an aftermarket exchange. ${ }^{75}$ If we observe two participants in a given auction market engaging in an after-market trade, and if the second assumption is correct, then the auction could not have been efficient. By contrast, in the OCS auction, in which values may differ because bidders have different information, and in which multiple nonidentical tracts are auctioned, after-market exchange may occur, because bidders reassess values based on information that the bids have revealed. Or, perhaps just as likely, bidders may want to acquire tracts in certain combinations, and they failed to do so in the primary auction. ${ }^{76}$ The publicity of prices at auctions all but guarantees that an inefficient award will be reallocated to the highest-value bidder in a subsequent private exchange. The highestvalue bidder, observing that the award was at a price below his willingness to pay, has an incentive to approach the winning bidder with a higher bid. 77

English auctions. In English auctions, if at any time the standing bid, $b_{j}$, is below the value to buyer $i$, then $i$ has an incentive to raise the bid by some amount no greater than $v_{i}-b_{j}$. In auctions with a standard bid increment, $d$, buyer $i$ would be prepared to bid $b_{i}=b_{j}+d$. This process of raising the standing bid will continue until buyers $l$ and 2 are the only active bidders. (See Figure 1). If the penultimate bidder, buyer 2, bids $b_{2}$ $=v_{2}-d$, then buyer 1 will be the final winning bidder with a bid of $b_{1}=v_{2}$, but if buyer 2's penultimate bid is $b_{2}=v_{2}$, then buyer 1 wins with a bid $b_{1}=v_{2}+d$. Hence, the theoretical English-auction price is $p_{e}=v_{2}$, or slightly above, depending on the auction's unstructured bidding dynamics and the size of the standard (or freely chosen, final) bid increment. Since buyer $l$ is the winning bidder, the allocation is efficient. These results all follow, because the English auction is a demand-revealing mechanism. The process is capable of enticing any buyer to bid value, if necessary. Only the highest-value buyer finds this full-value bid not to be necessary.

First-price auctions. The first-price, sealed-bid auction uses the same allocation and price-determination rule as the English auction-the high bidder wins and pays what he bids-but the analysis and predicted outcomes are completely different. This result occurs because of the different bid-information conditions in the two kinds of auctions. In the first-price auction, each bidder selects a single bid without benefit of any 
public bid information. Therefore, the amount that $i$ bids can depend only on $v_{i}$ and on $i$ 's assessment of the other bidders' actions. If $i$ bids $b_{i}=v_{i}$, this maximizes the chance that $i$ will win, but it guarantees a zero surplus $\left(v_{i}-b_{i}=0\right)$ if the bid wins. Hence, if $i$ believes that a bid in the amount of $v_{i}$ has some chance of winning, then there exists an inherent trade-off, in which bidding slightly less than $v_{i}$ yields a gain in surplus to be weighed against the reduced chance of winning. Any bidder $i$, who either is not extremely risk averse or has no special reason to believe that others will bid more, will hedge and bid less than $v_{i}$. Hence, we can predict that each $i$ will bid less than $v_{i}$. This is why the first-price, sealedbid auction is not a demand-revealing mechanism.

We can also predict that because bidders are likely to vary in their expectations about others' bidding actions and will vary in terms of their attitudes toward risk, they are also likely to vary in the extent to which they under-reveal demand by bidding less than value. These conditions increase the likelihood that the winning bidder will not be the highestvalue buyer. ${ }^{78}$ In Figure 1 , if buyer 1 is not averse to risk-taking, and if he expects others to bid low (because of depressed economic conditions or for other reasons), then his bid may be much below $v_{1}$. By contrast, if buyer 2 is very risk averse or not optimistic that others will bid low, then he may bid very close to his value. Under such conditions, the item could be awarded to buyer 2 . Hence, by comparison with the English auction, it seems less likely that the first-price auction will be efficient.

Without adding additional structure to the analysis, we can conclude nothing about what price to expect from the first-price auction. If the $N$ values, $v_{i}$, are regarded as independent occurrences from some interval between zero and $\bar{v}$, with all values in this interval being equally likely (in a sense this is a characterization of complete ignorance), and if all buyers are risk-neutral, expected-surplus maximizers, then we can show that a non-cooperative equilibrium-bid function for all $i$ is given by $b_{i}=(N-1) v_{i} / N{ }^{79}$ That is, the ratio of one's optimal bid to one's known value is just the proportion of the bids that will be rejected. We can also show that under certain assumptions about the risk-averse characteristics of the population of bidders, we can derive an equilibrium $\mathrm{bid} / \mathrm{value}$ ratio for each $i$, which lies above the Vickrey risk-neutral ratio, $(N-1) / N .^{80}$ Under Vickrey's assumptions, the expected prices in the first-price and English auctions are the same and are equal to the expected second highest value: that is, $E\left(p_{1}\right)=E\left(p_{e}\right)=E\left(v_{2}\right)=\bar{v}(N-1)(N+1)$. But, the modified model with risk aversion yields a higher expected price in the first-price auction; that is, $E\left(p_{l}\right)>E\left(p_{e}\right)$

Dutch auctions. Vickrey was the first to argue that the Dutch-auction institution calls for the same kind of strategic considerations as does the first-price auction. Each bidder must decide at what price to stop the clock, with no information from the auction itself about what competing bidders are prepared to bid. If the clock stops, then one learns what a competitor has bid, but then the auction is over. It is true that while the 
clock is still running, each bidder learns that at the previous higher prices, no bidder was willing to accept. But, this information is not very informative, because what each bidder needs to know is at what lower price the most eager buyer is willing to accept. Some have argued that the Dutch price will not be very much below the highest value, $v_{l}$, in Figure 1, because each bidder will be motivated to accept the offer as soon as it gets just below his value, to avoid losing to another bidder. ${ }^{81}$ This argument ignores the gain in surplus at a lower price, which must be weighed against the "cost" of an increased risk of losing the item to another bidder ${ }^{82}$ Formal analysis of the Dutch auction suggests that it will be equivalent (yield the same price and efficiency) to the first-price auction, and this equivalence holds under various alterations in the assumptions. ${ }^{83}$

Second-price auctions. Vickrey introduced this auction procedure in answer to the rhetorical question: Is there "some sealed-bid procedure that would be logically isomorphic" to the English auction?84 This auction has incentives very different from those of the first-price auction, because each bidder knows that, if he is the highest bidder, except for ties, then the price paid will be independent of the amount bid. Hence, the higher $i$ s bid, the greater is the chance that he will win, with no corresponding reduction in surplus, because surplus to $i$ is $v_{i}-b_{j}$, if $i$ is the highest bidder and $j$, the second-highest bidder. Each $i$ has an incentive to bid his value, $v_{i}$, as a means of maximizing the chance of winning, regardless of his attitude toward risk. ${ }^{85}$ It would not be optimal for $i$ to bid more than $v_{i}$, because if $i$ wins and the next highest bid is greater than $v_{i}$, then a loss is incurred. Thus, in Figure 1 each $i$ has an incentive to bid $b_{i}=v_{i}$. If all bidders do this, then buyer $l$ is awarded the item at price $p_{2}=v_{2}$, the theoretical price in the second-price auction. By this reasoning the second-price auction yields the same efficiency, and essentially the same price, as the English auction.

Comparative theoretical properties of the standard auctions. In the theory of English and second-price auctions, the outcomes are competitive, in the sense that the allocations are efficient, and every award is at the price $v_{2}$ in Figure 1, which is the lowest price that equates supply (one unit) with demand. These theoretical results hold for any number of bidders $N \geqslant 2$, and they are independent of individual attitudes toward risk. Provided only that more surplus is better for each bidder, in the English auction bids must continue to increase until $v_{2}$ is reached, and in the secondprice, sealed-bid auction it is a dominant strategy for each bidder to bid his value, which yields the price $v_{2}$. If we add Vickrey's assumption, that the $v_{i}$ are drawn from the uniform distribution defined on the interval from zero to $\bar{v}$, then the expected value of price in the English and second-price auctions is the expected value of the second highest among a sample of $N$ values; that is $E\left(p_{e}\right)=E\left(p_{2}\right)=E\left(v_{2}\right)=\bar{v}(N-1) /(N+1)$. Thus, the expected price to the seller approaches the maximum possible value, $\bar{v}$, as $N$ is increased. This result does not mean that the market becomes "more competitive" with large $N$. It means merely that the chances grow 
larger that the second highest value will be near $\bar{v}$. In this non-cooperative theory, the market is just as competitive, in the sense that awards are efficient and at a market-clearing price, whether $N=2$ or $N=100$.

In the Dutch and first-price auctions, we can articulate no specific theory of price and allocation without introducing assumptions about the distribution of values and the bidders' attitudes toward risk. If we apply Vickrey's assumption, then the outcomes in these two auctions will be competitive in the sense that the allocations are efficient. But, since the awards are at the price $v_{l}(N-1) / N$, they need not be at a price that equates supply and demand. The expected value of this price is $E\left(v_{1}\right)(N-1) / N=E\left(v_{2}\right)=$ $\bar{v}(N-1) /(N+1)$, however, and the awards are competitive in the sense that on average the price is the lowest price that clears the market. Consequently, outcomes in the Dutch and first-price auctions are competitive in a much weaker sense than are the corresponding outcomes in the English and second-price auctions. To illustrate this proposition suppose that there are two bidders, with $v_{1}=10$ and $v_{2}=6$. Under the Vickrey assumptions each bidder knows his own value and knows that he can regard both values as drawn from a uniform distribution. If each person bids to maximize expected surplus, on the assumption that the other person will do likewise, then bidder 1 bids $b_{1}=v(N-1) /(N)=5$, while bidder 2 bids $b_{2}=v_{2}(N-1) /(N)=3$. The award goes to bidder 1 at price 5 in a Dutch or first-price auction, and this price is below the lowest market-clearing price, which is 6 . But, in an English or second-price auction, the award goes to bidder 1 at price 6 . If the values were $v_{1}=14$ and $v_{2}=6$, then the Dutch or first-price auction award would be at price 7, which is higher than the price (6) in the English and second-price auction. These differing outcomes occur, because the probability distribution of prices is different in the Dutch and first-price auctions than it is in the English and second-price auctions. But, since the two distributions happen to have the same expected value, we can expect prices on average to be the same in the two sets of institutions. In the Dutch and first-price auctions, the larger is $N$, the closer is each person's bid to his value, and, as in the English and second-price auctions, the expected price approaches $\bar{v}$.

If we replace Vickrey's assumption, that bidders are risk neutral, with the assumption that they show different degrees of risk aversion, ${ }^{86}$ then the allocations are no longer necessarily efficient and expected prices are increased in the Dutch and first-price auctions; that is, $E\left(p_{d}\right)=E\left(p_{1}\right)>\bar{v}(N-1) /(N+1)=E\left(p_{e}\right)=E\left(P_{2}\right)$.

Effect of positively dependent values. Suppose that individual buyers' values are not independent, because for at least some persons, the item's value would increase upon learning that others value it more highly than they do. For example, an oil company might value an OCS tract at $\$ 100$ million, but revalue it upward on learning that one or more other companies assess its value in excess of $\$ 100$ million. This revaluation could occur with any property whose value is based on geophysical or other 
tests or upon expert appraisal, as with art objects. That in some English auctions certain well-known buyers or dealers go to great lengths to preserve the secrecy of their bids suggests that they think that this information might affect others' bidding. Cassady reports the incident in which Norton Simon was bidding for Rembrandt's Titus in Christie's auction house. ${ }^{87}$ Simon had a written agreement that stipulated a complicated set of bidding signals. The auctioneer got lost in the procedure and awarded the painting to another bidder, before being challenged by Mr. Simon, who was indeed the high bidder. It is difficult to understand examples such as this, except in terms of some concept of positively dependent values. ${ }^{88}$

Milgrom and Weber provide a formal analysis of the effect of positive value dependence on the various standard auctions. ${ }^{89}$ As one might expect from the different auctions' defining characteristics, the English auction's results are affected when values are positively dependent. The effect increases price, because as the bidding progresses, the nature of the process compels people to reveal their (provisional) willingness-topay, which makes it possible for others to adjust their personal valuations, and so on, until the process stops. Milgrom and Weber also find that the Dutch and first-price auctions maintain their equivalence with positively dependent values, but the English and second-price auctions no longer remain equivalent institutions.

Fair market value and the standard auctions. If the property at auction is an OCS tract available for lease, then the value, $v_{i}$, might represent each company's estimate of the value of leasing the tract, given the lease's dimensions, such as the royalty rate, and so forth. These values would represent the object's value ex ante the realization of the uncertain future variables, such as geological conditions, oil and gas prices, and so forth. Referring to Figure 1, and assuming the independence of values, we notice that there are natural definitions of several of the concepts of "fair market value" discussed earlier. ${ }^{90}$

If "fair market value" means the highest possible payment to the government, then its achievement requires that $v$, be paid to the government. But, we can expect none of the auctions discussed here to attain that goal. Indeed, we know of no auction process or other pricing mechanism that will do so. A second definition of "fair market value" discussed earlier is that the government receives a payment that just exhausts the willingness to pay of all losing bidders.91 In terms of Figure 1, this definition requires that the government receive $v_{2}$. Under the assumptions of this example, the second-price and English auctions have the theoretically derived property that all bidders fully reveal demand. Hence, the payment to the government is predicted to be $v_{2}$.

These two alternative concepts of "fair market value" are separated by the amount $\left(v_{1}-v_{2}\right)$. This difference suggests another natural definition of "fair market value" to be $f\left(v_{I}+v_{2}\right) / 2$, the midpoint between $v_{l}$ and $v_{2}$. The price $f$ guarantees an efficient allocation, clears the market 
(only one buyer desires the single available unit at that price), and splits the difference in the potential seller revenues that separates the previous two definitions of "fair market value."

Since $v_{2}$ is the tract's opportunity cost, we can also interpret the price $f$ as splitting the difference between the tract's (demand) value, $v_{1}$, and its (opportunity) cost, $v_{2}$. From our analysis of the four standard auctions, the first-price auction and its theoretical equivalent, the Dutch auction, might come closest in practice to approximating $f$ by yielding a mean price near $E(f)$. If prices are higher in the first-price auction than in the second-price or English auctions, because of risk-averse bidder decision making, then average prices near $E(f)$ may occur. But, we know of no auction or other pricing mechanism for which the theoretically predicted price is necessarily at or near $E(f)$.

C. The Performance of Experimental Auction Markets

We can easily reproduce the conditions illustrated in Figure 1 in a controlled laboratory experiment. The procedure is to assign each of $N$ randomly generated values, denominated in dollars, to $N$ distinct buyer subjects, with the understanding that the winning bidder in any auction will be paid the difference between the winner's assigned value and the price determined in the auction. Hence, the subjects' incentives in an experimental auction are identical to the representation given in Figure 1 for any auction. For example, in Figure 1 if subject $l$ with value $v_{t}$ eventually announces the final bid, $v_{2}$, then subject $l$ "earns," or is paid, $v_{1}-v_{2}$ dollars. If all participants prefer more cash to less, then each $i$ will be motivated to bid no higher than $v_{i}$. Thus, $v_{i}$ provides an upper bound on $i$ 's willingness to pay for an abstract object in an experimental auction. The most common experiment using cash-motivated subjects consists of a sequence of ten or more auctions, each with a different random assignment of values among the $N$ subjects, with each auction guided by the rules that define one of the four standard auctions. ${ }^{92}$ Since the goal of the experiment is to test the Vickrey auction models, the experimental conditions reproduce Vickrey's information and structural assumptions. That is, each subject knows his assigned value before tendering a bid in each auction. And, each subject knows the probability distribution from which all values were drawn, but he does not know the particular value that this procedure assigns to any other bidder. The usual experiment is replicated more than once, with a different group of $N$ subjects. Experiments using the same or distinct groups, also of size $N$, but different auction rules, allow the different auction institutions to be compared. Varying $N$ across experiments with each of the auction institutions allows one to discern any effects attributable to the number of bidders. These are just the classical methods of experimental science applied to the study of auctions in which the treatment variables can be the number of bidders, the institution (kind of auction), the distribution of values provided to each person (each subject knows his own value, and the distribution from which other values are drawn at random). 
Table 1 summarizes the mean observed price for various values of $N$, for each of the four standard auctions. These data are based on a total of 852 auctions conducted in 28 experimental sessions. The Dutch-auction experiments for $N=8$ in 'Table 1 are not comparable with the other Dutch auctions, because they are conducted under different control conditions. ${ }^{93}$ These data support the conclusion that English-auction prices are below Dutch-auction prices. Also, mean Dutch prices are below those in the first-price auction, for all values of $N$ studied. Finally, the lowest mean prices occur in the second-price, sealed-bid auction. But, this last result is somewhat misleading, because there is evidence that over time an increasing number of subjects in second-price auctions submit bids equal to their respective values. ${ }^{94}$ Hence, bidders appear to "learn" over time that it is in their self-interest to bid their maximum willingness-topay. Except for the case in which $N=3$ (Table 1), both Dutch- and firstprice-auction mean prices are above Vickrey's risk-neutral prediction, which is consistent with the hypothesis that bidders act as if they are risk averse. Nevertheless, it also remains clear that in these experiments the Dutch auction is not equivalent, in terms of the subjects' actual decisions, to the first-price auction. Mean Dutch prices are consistently below prices in first-price auctions, and therefore the theory of the Dutch auction, which ignores the information and technical differences between the Dutch and first-price auctions, is deficient.

That mean Dutch and first-price auction prices tend to be below Vickrey's prediction when there are only $N=3$ bidders suggests that some sort of tacit collusion may occur; "tacit" is the right word, because the subjects could not communicate during an experiment. We can offer no other explanation of these results, which disappear when $N \geq 4$.

In Table 1, column 5, curiosity led us to compute the expected value of $f=\left(v_{1}+v_{2}\right) / 2$, which is well-defined by the treatment conditions of the reported experiments. It turns out that under the conditions of these particular experiments, the first-price auction, except, again, for the case of $N=3$, yields mean observed prices that appear remarkably close to this concept of expected "fair market value." In particular, for all $N \geq 3$, expected fair market value is a better predictor of the mean price than is Vickrey's expected risk-neutral price.

We can obtain additional insight into the comparative performance of the different auctions, as well as a strengthening of our conclusions, from the efficiency data reported in Table 2. Efficiency is measured here as the percentage of auctions, conducted according to a given set of rules, in which the award is to the bidder with the highest value. Thus in the English auction sessions $(N=8), 35$ of the 36 auctions (97 percent) represented efficient allocations. From Table 2 we see that the English auction shows the greatest efficiency, with the second-price auction only slightly less efficient than the English auction. The first-price and especially the Dutch auctions are considerably less efficient than either the English or the second-price auctions. We note in particular that an efficiency order- 


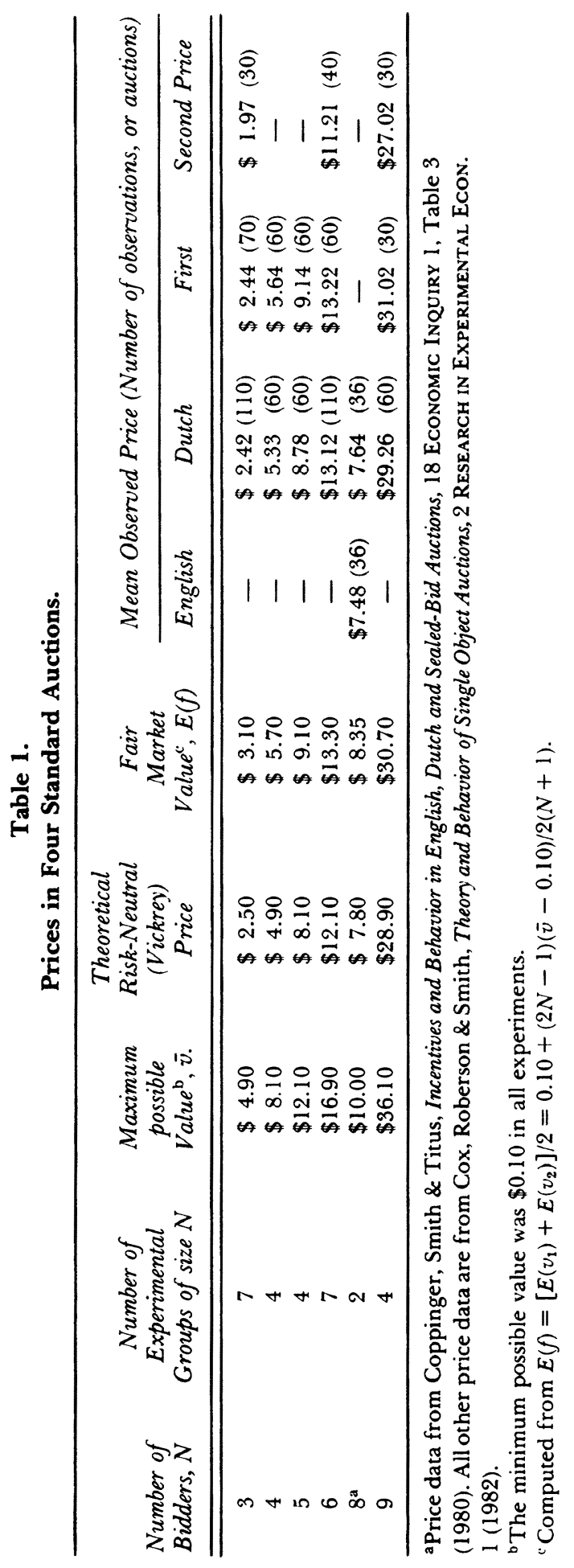


Table 2.

Efficiency, Percentage Awards to Subject

with Highest Value.

\begin{tabular}{ccccc}
\hline $\begin{array}{c}\text { Number of } \\
\text { Bidders }\end{array}$ & English & Dutch & First Price & Second Price \\
\hline \hline 3 & - & 82 & 83 & 93 \\
4 & - & 77 & 95 & - \\
5 & - & 82 & 93 & - \\
6 & - & 84 & 83 & 97 \\
$8^{\text {a }}$ & 97 & 78 & - & - \\
9 & - & 72 & 83 & 90 \\
\hline Overall & 97 & 80 & 88 & 94 \\
\hline
\end{tabular}

${ }^{a}$ See Table 1.

ing of the institutions is almost the reverse of an ordering based on price. Thus, the first-price and Dutch auctions, which yield the highest prices to the seller, are the least efficient; the English and second-price auctions, which provide the lowest prices, are the most efficient.

These experimental results provide empirical evidence of a direct conflict between efficiency and price, in comparing the various standard auctions. No experimental studies have been made of the performance of different auctioning institutions under the information and multipleunit-offer conditions of the OCS tracts. But, a reasonable conjecture is that a similar conflict may prevail in the OCS paradigm.

It is natural to ask, "Why should the government worry about the efficiency of auctions if it takes in more money from inefficient auctions?" The answer is that the government need not concern itself with efficiency if its only objective is to maximize its revenue from the sale of OCS tracts. But, as we interpret the OCS legislation, the government states that the goals of OCS leasing include maintaining competition and promoting the timely discovery and development of new oil and gas sources on OCS lands. ${ }^{95}$ An important property of competitive markets is that resources are allocated to their highest-valued use. In the case of OCS tracts, those companies best able to profit from the discovery and development of particular OCS tracts are those for whom such tracts will have the highest value. Consequently, the government's stated goals should include concern for whether these tracts get allocated to the bidders that value them most highly. But, as we find in the discussion of the standard auctions, if there is uncertainty about value, the different information and incentive properties of different kinds of auction institutions may imply that the less efficient auctions yield higher prices. ${ }^{96}$

Of course, this problem is mitigated if there is free after-market 
exchange. That is, in an inefficient primary auction, a subsequent exchange can yield an efficient allocation. But, the use of an after-market adds to the participants' cost of transacting. Also, if the government chooses an inefficient auction method and subsequently observes that the winning bidder resells a tract to someone else at a higher price, then the government must guard against concluding, from this evidence alone, that there must have been a conspiracy in the primary auction. The experiments that we describe provide no opportunity for explicit communication and therefore within the structure of the experiments offer no opportunity for formal bidder agreements. Yet, inefficient allocations occur as a property of the incentive and information conditions of the Dutch- and first-price auction institutions. If these results also characterize OCS auctions, then perhaps the first-price auction procedure that is used provides a reasonable compromise between price and efficiency; that is, this procedure yields the highest average price, but it is not the least efficient institution.

\section{Information and the Collusive Potential of Alternative Auctions}

The theory of auctions previously summarized is a non-cooperative theory, based on the hypothesis that people act independently in the sense of not acting in concert by tacit or explicit agreement to influence the price or the allocation. Non-cooperative theory assumes that people will choose bids that are conditional upon what others bid or are expected to bid, but that no bid or bids reflect tacit or explicit joint agreements among any of the participant buyers or seller.

Because it is widely believed, often alleged, and sometimes documented that collusive buyer rings may influence an auctioned item's price, it is important to examine the different standard auctions in terms of their manipulative possibilities. ${ }^{97}$ Here, we discuss three kinds of collusion: buyer rings, in which two or more buyers enter into an agreement to act in concert; an agreement between the auctioneer and one or more buyers to act in concert; and, manipulative actions by the seller, in the case of private auctions, or in concert with the auctioneer, in the case of organized public auctions.

Buyer rings. Before discussing the mechanics of colluding buyer rings and how the different standard auctions might affect their operation, a few general observations may provide some perspective on the issue. In many auctions of single objects that are offered for sale, especially paintings and other works of art, the sellers are monopolists, who enjoy all of the advantages ordinarily thought to be the privileges of monopoly. Such sellers are free to offer or not to offer to sell, and if the decision is to offer for sale, then the seller is free to choose any reservation price (minimum acceptable bid) that is agreeable to the auction house. Given this menu of choice, for the monopolist to complain that buyers may sometimes form a ring is a bit like the fox complaining about farmers who fence their chickens. 
Indeed, buyer rings may function as a form of countervailing power to a seller's monopoly or monopoly-like dominance. Tacit collusion by buyers, in which demand is withheld (under-revealed), has been documented experimentally under monopoly pricing, with such buyer collusion found to be greatly reduced if there are two sellers. ${ }^{98}$ Similarly, in 1980 the airlines were reported to have withheld orders for Boeing's new 757 jet, in the hope that McDonnell Douglas would elect to offer a competing jet in the same class. ${ }^{99}$ Although the government is not a monopoly owner of oil- and gas-leasing rights, most of the remaining unexplored potential oil- and gas-bearing lands are offshore or on public lands, which constitute over one-fourth of the land area of the United States. Because of its choice of reservation prices and the time rate at which it places leases at auction, the government's market power seems easily as great as that of any bidder or any combination of bidders.

Suppose that a subset of $n$ buyers, such that $n \leq N$, agrees to act cooperatively. If cooperation is to be achieved, all of the ring's members must agree on which member is to receive the item; on the price-determining bid to be entered by one of the members, with all others entering "shill" (fake) bids designed to give the appearance of an open auction; and on the compensation to be paid by the member receiving the item to the remaining $n-l$ ring members in return for their forbearance. An agreement this extensive requires a cohesive group, such as might exist among a small group of antique dealers. The conditions most favorable to the ring are that the ring includes all or most of the bidders with the highest values, and that the item will be resold by the receiving member of the group, say, at retail outside of the group, or in an "open" auction restricted to the group, thus yielding a well-defined arbitrage profit that the ring members will share.

Even under these conditions if there is insufficient "honor among thieves," then the reselling dealer may sell the item at a shill price modestly above the ring's purchase cost and arrange a private "kick back." Or, if the item is resold at "open" auction to the ring, then there may be a ring within the ring. Plainly, the more successful is a ring, the greater is the incentive for a ring member or members to exploit the agreement for private gain. To avoid this exploitation, the ring must devise effective monitoring and enforcement procedures. But, monitoring may be costly, even if it is feasible, and punishment by expelling a deviant member merely provides the ring with one more external competitor.

If conditions are less favorable, a ring may encounter more serious difficulties. If the ring does not include the highest-value bidder, then it is almost certain to be unsuccessful in an English or second-price auction. But, it may have some chance of success in a Dutch or first-price auction, if the highest-value buyer is not very risk averse or is otherwise motivated to bid considerably below his value. If the ring includes the highest-value buyers, say, the top two, but not the third highest, then the ring can be assured of success only if it adopts a bidding strategy that will ensure a 
price at least as large as $v_{3}$ in Figure 1. Such a strategy is more likely to be devised in an English auction than in any of the other auctions. In an English auction the ring members could simply agree not to bid against each other and to accept, as the ring's purchase cost, the highest necessary bid. In our example member 1 or 2 will be the winner at a price $v_{3}$ or a little higher. In English auctions in which bidder anonymity is preserved, an agreement among ring members not to bid against each other requires all ring members to have common knowledge of member signaling codes, and to be seated at auction so as to be able to read the signals. This is an imposing task, because bidders normally face the auctioneer. 100

The Dutch and sealed-bid auctions make it impossible for a ring to use this kind of conditional bidding strategy. With respect to the OCS auctions, it is an open question whether it is in the government's interest to reveal the bids and identities of all bidders after an auction is completed. If a buyer ring is operating in OCS auctions, then such bid information makes it easier for the ring to monitor its members' actions, to learn who, when, where, and at what bids the ring lost to outsiders, and to adjust the ring's strategies accordingly. From this perspective the Dutch auction is probably best, because none of the losing bids are known to anyone, and they cannot even be leaked. In sealed-bid auctions all bids are known by someone, and a policy of not publicizing bids means only that bid information is not generally available at zero cost. ${ }^{101}$ Observations such as these should lead to an appreciation of the ingenious characteristics that may be captured in the various standard auction institutions, whose origins and circumstances of birth are unknown.

Auctioneer and/or seller collusion. We must modify most of the preceding discussion if the auctioneer, as agent for the seller, is party to an agreement with any buyer or ring of buyers. In the case of a ring, at an English auction with bidder anonymity the auctioneer merely can feign to have recognized signals from the floor when he is actually implementing the ring's agreement that no member raise the bid of any other member. But, the pivotal importance of the auctioneer in this case suggests that his services are not likely to be cheap. Indeed, theoretically he can extract most of the ring's profits, and no ring member is well motivated to punish the auctioneer by revealing his role to the authorities. In the case of sealed-bid auctions, a ring could be secretly notified of the bids of nonmembers, with the ring submitting new replacement bids to the auctioneer, who then "opens" the bids for public announcement of the results. The terms of an agreement between any one buyer and the auctioneer in a first-price auction might include that if at any time that buyer enters the highest bid, then the auctioneer will allow that buyer to resubmit a new bid just above the second-highest bid. Similarly, as Vickrey notes, the second-price auction is vulnerable to a "shill" bid just below the top bid, to extract a higher price from the top bidder. ${ }^{102} \mathrm{By}$ this device, if bidders all reveal maximum willingness to pay, then the seller can extract the maximum possible surplus. 
This example raises another issue in connection with the question of whether bids should be announced after an auction, namely the auction's institutional credibility. The advantage in this case of announcing all bids, or at least the top two bids, is that bidders can verify that their bids are processed honestly, and hence their bidding strategies do not have to include an additional source of strategic uncertainty growing out of potential fraud.

\section{E. Combinatorial Auctions}

The combinatorial auction is a sealed-bid auction in which individual bidders can submit bids for one or more combinations of nonidentical items in a multiple-unit auction. ${ }^{103}$ In a combinatorial OCS auction, in which many tracts are offered at auction, a bidder whose test information suggests that three particular contiguous tracts have the best prospect for a petroleum discovery could enter a bid on the three-tract package and also submit bids for the individual tracts, if he so desired. The three tracts may have a combined value to the bidder that exceeds the sum of the component tracts valued in isolation, perhaps because of the greater flexibility that the combined tracts provide in identifying the character and extent of the geological structure on which preliminary tests have been conducted. The combinatorial auction procedure also permits bidders to enter various conditional bids. For example, these might include a bid for the package of tracts $A, B$, and $C$, and a bid for the package $D$ and $E$, but with the understanding that either but not both can be accepted; or, they might include a bid for tracts $A, B$, and $C$, and for $D$ and $E$, and for $F$, with the total dollar amount of the accepted bids not to exceed some limit that the bidder specifies. If combination values exceed the sum of component values, then only the combinatorial procedure allows the bids to reflect the offering's full potential value, thus facilitating efficient allocation.

The allocation of tracts among bidders in the combinatorial auction requires a computer algorithm that could make awards, to maximize the offering's total surplus, as the bids reveal under a procedure in which winning bidders pay less than the amounts bid (as in the second-price, sealed-bid auction). Or, the algorithm could make awards, to maximize the seller's total revenue, as determined by the bids under a procedure in which winning bidders pay the amount bid, as in the first-price, sealedbid auction. Which allocation procedure actually yields higher revenue to the seller is an empirical question that has not yet been examined experimentally, but we expect the first procedure, maximizing total surplus, to be more efficient than the second, maximizing total revenue, because the first provides better incentives for demand revelation. Since bidders have an incentive to bid higher under the first procedure than under the second, the second would not necessarily yield the greater revenue to the seller. But, experiments comparing combinatorial auctions using the first procedure with noncombinatorial auctions have been conducted, and the 


\section{Supreme Court Economic Review}

results show that the combinatorial auction yields the highest efficiency. ${ }^{104}$

If the total value of tracts in the OCS auction is significantly greater in package combinations than in separate components, then the combinatorial auction institution may be the most important alternative to current procedures that the government might consider. The extent of after-market exchange in past OCS auctions that involved the assembly of individual tract awards into packages, or the extent of joint exploration and development contracting among the winners of different tracts, would provide partial evidence of interdependent tract values.

Because the bids have information value to the other bidders, a research question of some interest is whether the combinatorial sealedbid auction should be modified to allow individual bids to be tendered that are conditional upon other bids. For example, company $A$ might wish to bid $\$ 100$ million for a particular combination of tracts, with the condition that the bid be raised to $\$ 110$ million if any other company bids on the same combination, or if anyone else bids more than $\$ 100$ million, and so on. Of course, such a conditional increase in one's bid is always possible in the English auction. Would such conditional bids increase or diminish the efficiency of primary auction allocations? Would they increase or diminish revenue to the seller? These are among the important research questions, along with the question of how the combinatorial auction compares with the current practice of simultaneous bidding for separate tracts.

\section{SUMMARY AND CONCLUSION}

The 1978 Amendments to the OCS Lands Act provide an example of the kind of legislation that economists find interesting, because it authorizes the creation of some new market institutions. These new institutions are the nine auctions authorized for use in selling federal leases on OCS tracts, as alternatives to the traditional cash-bonus-bid, fixedroyalty-rate lease auction. Of further interest, the legislation requires the use of some of the new auctions, within broadly specified percentages of lease sales, and it requires the Secretary of the Interior to report regularly to Congress on the performance of those newly authorized auctions that he uses. In this way, the 1978 Amendments require the Secretary to conduct a field experiment in auction-market performance.

The plaintiffs in Energy Action alleged, inter alia, that the Secretary abused his discretion in not using any of the newly authorized auctions that provide for bidding on variables other than the size of the cash bonus. We can interpret this claim as an allegation that the Secretary was subverting the legislation's intent and biasing the mandated field experiment's conclusions by not using any of the auctions that provide for bidding on the downstream payment terms of leases. 
Section II analyzed some properties of all ten of the authorized auctions. ${ }^{105}$ It began by observing the inverse relationship between the size of the up-front payment and the expected downstream payments that can be obtained on a lease on any given OCS tract. Furthermore, higher front-end lease payments lead to a smaller number of separate bidding entities capable of bearing the risk of such payments. In addition, higher downstream payments, in relation to downstream production revenues, can imply a disincentive for efficient exploration and development of leased tracts. Hence, one possible interpretation of the basic issue of economic policy underlying the legal issues in Energy Action is an implicit disagreement over the relative importance of increasing the number of lease-auction bidders versus promoting efficiency in the exploration and development of leased tracts.

The theoretical analysis in Section II implies that some of the newly authorized auctions contain lease provisions that would undermine efficiency in exploration and development of leased tracts. ${ }^{106}$ Hence, the Secretary may have been well advised in not using them. Finally, the theoretical analysis implies that the net-profit-share auctions are the most promising for increasing the relative size of downstream payments on leases, while diminishing the relative size of up-front payments, without introducing serious disincentives for efficient exploration and development of leased tracts. ${ }^{107}$

Theoretical analysis by itself cannot provide satisfactory answers to questions about comparative auction performance. Thus, it is encouraging that Congress sought empirical data on auction performance. But, as Section III pointed out, there are serious methodological problems that arise in conducting field experiments, to compare the properties of alternative OCS-lease auctions. ${ }^{108}$ We contrast the requirements of a controlled experiment on auctions with the field conditions in OCS lease auctions and conclude that there is not sufficient control of determining variables to permit the derivation of valid empirical answers to some central questions. We then argue that controlled laboratory experiments on auction markets would provide useful complements to field experiments, and that laboratory techniques would have several advantages over virtually any feasible field experiment.

As Section IV explains, there is a rich body of work involving laboratory tests of some hypotheses of auction performance. ${ }^{109}$ Although there are some differences between the auction environments that have already been tested in the laboratory and the environment of the authorized alternative processes applied to OCS auctions, this literature is enlightening nevertheless. It demonstrates that auction rules do matter. It highlights some properties of the first-price, sealed-bid rule common to the traditional and alternative OCS auctions, compared with kinds of auctions not mentioned in the 1978 Amendments. And finally, the existing work demonstrates the ability of this relatively new research technique to 
address precisely the kinds of economic issues that the 1978 Amendments and Energy Action raised.

\section{NOTES}

1. 454 U.S. 151 (1981).

2. 43 U.S.C. § 1331 et seq. (1976 \& Supp. IV 1980).

3. It would be impossible to provide here a complete bibliography on auctions and on experimental methods in economics. The following references are good primary sources with extensive bibliographic information: R. Cassady, Auctions and Auctioneering (1967); Milgrom \& Weber, A Theory of Auctions and Competitive Bidding, 50 EconometriCA 1089 (1982); and Smith, Microeconomic Systems as an Experimental Science, 72 AM. Econ. Rev. 923 (1982).

4.43 U.S.C. \& 1331 et seq. (1976 \& Supp. IV 1980).

5. Energy Action Educ. Found. v. Andrus, 479 F. Supp. 62 (D.D.C. 1979).

6. Energy Action Educ. Found. v. Andrus, 631 F.2d 751 (D.C. Cir. 1979).

7. 454 U.S. at 168-69.

8. 43 U.S.C. $\S 1337$ (a)(5)(B) (Supp. IV 1980).

9. The Court's decision also at one point calls the Secretary's task "experimentation" and mentions several times the requirements that the Secretary report periodically to Congress. 454 U.S. at 162-65.

10. See infra notes 11-13 and accompanying text.

11. 43 U.S.C. § 1332(3)-1332(4) (Supp. IV 1980).

12. 43 U.S.C. \& 1344(a)(4) (Supp. IV 1980).

13. H.R. REP. No. 1474, 95th Cong., 2d Sess. 92 (1978).

14. See, e.g., 454 U.S. at $162,164,165$.

15. 43 U.S.C. § 1344(a)(4) (Supp. IV 1980).

16. 43 U.S.C. $\S 1331$ (1976 \& Supp. IV 1980).

17. Id. § 1331 (o) (Supp. IV 1980).

18. H.R. REP. No. 1424, 95th Cong., 2d Sess. $77-79$ (1978).

19. See 43 U.S.C. \& 1331 (c) (Supp. IV 1980), and H.R. REP. No. 1474, 95th Cong., 2d Sess. 78 (1978).

20. Id.

21. The "generous" interpretation of congressional intent was suggested by referees of an earlier draft of this essay and is based on H.R. REP. No. 1474, 95th Cong., 2d Sess. 79 (1978), in which the conferees state, "This term [fair market value] as defined in subsection (o), is only used in this act in relation to the purchase and distribution of oil and gas under section 27." Our skepticism that one can thus eliminate any idea of ex post valuation from congressional intent is based on two arguments. First, the "generous" interpretation of this passage leaves the key phrase "fair market value" undefined for the parts of the legislation concerning leases. Second, the section of the same Conference Report concerning the "fair market value" of leases makes it clear that the Senate had precisely this ex post vantage point. The Report reads:

Both [the House and Senate versions of the bill] contain as a consideration of a leasing program, the receipt of value for lands. The House Amendment provides that activities are to be conducted to assure receipt of "fair value for the lands leased and the rights conveyed by the Federal Government." The Senate bill provides for leasing activities to be conducted to assure receipt of "fair market value for the oil and gas owned by the Federal Government." The Conference Report follows the House amendment with the addition of the term "market" so as to read "fair market value for the lands leased and the rights conveyed by the Federal Government." Id. at 103.

Furthermore,. the respondents "complained that bonus bidding cannot generate adequate 
competition to yield a fair market return for OCS oil and gas as required by the 1978 Amendments." 454 U.S. at 158 (emphasis added).

22. Many of these times the term's use is in a quotation from a congressional committee report. In addition to the quotation in supra note 21 , the Court's opinion quotes S. Rep. No. 284, 95th Cong., 1st Sess. 46-47, 73 (1977); H.R. Rep. No. 590, 95th Cong., 1st Sess. 47, 54, 138-39 (1977); and H.R. ReP. No. 1474, 95th Cong., 2d Sess. 92 (1978). See 454 U.S. at 162 n.14, 164 n.16, 166 n.18.

23. Referees of an earlier draft of this essay pointed out that the federal government does not own all possible oil and gas leases. Furthermore, the value of oil and gas leases is critically dependent upon the expected price path of the resources, and the federal government is not a monopolist in these markets. We do not believe that these are sufficient conditions to ensure that the federal government, as a consequence, faces a perfectly elastic demand for OCS leases.

24. H.R. ReP. No. 590, 95th Cong., 1st Sess. 47 (1977). The full quotation is: "To increase competition for off-shore leases and secure higher returns to the public Treasury, section 8 of the Outer Continental Shelf Lands Act has been amended to allow the Secretary to use other bidding methods based on net profits; royalty; or work commitments stated in dollar amounts." Quoted in 454 U.S. at 167 n.18.

25. The Court held that "[i]n alleging that the bidding systems currently used by the Secretary of the Interior are incapable of producing a fair market return, California clearly asserts the kind of 'distinct and palpable injury' that is required for standing." 454 U.S. at 161 (citation omitted) (quoting Warth v. Seldin, 422 U.S. 490, 501 (1975)).

26. See infra text accompanying notes 38-51.

27. See, e.g., Cox, Roberson \& Smith, Theory and Behavior of Single Object Auctions, 2 Research in Experimental. Econ. 1 (1982); Forsythe \& Isaac, Demand Revealing Mechanisms for Private Good Auctions, 2 Research in Experimental Econ. 45 (1982); and Vickrey, Counterspeculation, Auctions, and Competitive Sealed Tenders, 16 J. Fin. 8 (1961).

28. See infra text accompanying notes 72-96.

29. See infra text accompanying notes 74-85.

30. The Court noted that " $t]$ he Secretary of the Interior has not experimented, however, with any of the systems using a factor other than the size of a cash bonus as bidding variable." 454 U.S. at 157 (emphasis original) (footnote omitted). And, it argued that "[ $t$ ]he essence of California's complaint ... is that the Secretary of the Interior, by failing to test non-cash-bonus systems, has breached a statutory obligation to determine through experiment which bidding system works best." 454 U.S. at 161.

31. See, e.g., Reece, Competitive Bidding for Offshore Petroleum Leases, 9 BeLL J. Econ. 369 (1978), and Wilson, A Bidding Model of Perfect Competition, 44 Rev. Econ. Stud. 511 (1977).

32. See Milgrom \& Weber, supra note 3.

33. See J. Cox \& R. M. Isaac, In Search for the Winner's Curse (1983) (Discussion paper, University of Arizona Dept. of Economics).

34. H.R. ReP. No. 590, 95th Cong., 1st Sess. 47 (1977).

35. See Wilson, supra note 31 .

36. Here, we abstract from the differential income-tax treatment of the write-off of lease bonuses for productive and relinquished leases. As a reader of an earlier draft of this essay pointed out, different tax treatments are applied to the write-off of the bonus, depending on the production rate if the tract is developed or the abandonment rate if the lease is relinquished during the diligence period. Because a similar argument applies to development costs, a substantial amount of risk sharing does fall on the government, even in pure cash-bonus bidding under current income-tax law.

37. These problems are explored in Forsythe \& Isaac, supra note 27, and in Rassenti, Smith \& Bulfin, A Combinatorial Auction Mechanism for Airport Time Slot Allocation, 13 BELL J. ECON. 402 (1982). See also infra text accompanying notes 103-104.

38. See Reece, supra note $31,: \rightarrow$ Smith, Non-Aggressive Bidding Behavior and the "Winner's Curse," 19 ECON. INQuiry 380 (1981). 


\section{Supreme Court Economic Review}

39. 45, Fed. Reg. 9,536 (1980).

40. The GNP fixed-weight price index is an index of the prices of all goods and services that comprise the GNP. The fixed weights that are currently applied to prices are 1972 expenditure shares in GNP. The index is regularly published in U.S. DEPARTMENT OF Commerce, Bureau of Economic: Analysis, Surv. of Current Bus.

41. 45 Fed. Reg. 36,784 (1980).

42. Accounting procedures for calculating expenses and profits are set out in 10 C.F.R. 390 (1983).

43. 45 Fed. Reg. 9,536 (1980).

44. 46 Fed. Reg. 29,680 (1981).

45. Accounting procedures for calculating expenses and profits are set out in 10 C.F.R. 390 (1983).

46. 46 Fed. Reg. 35,614 (1981).

47. 43 U.S.C. $\S 1331$ et seq. (1976).

48. 43 U.S.C. § 1331 et seq. (1976 \& Supp. IV 1980).

49. "Risk" refers to uncertain returns, whether positive or negative. Thus, if part of the payment to the government is a contingent royalty payment, then the government bears some of the risk associated with the lease's uncertain value.

50. 10 C.F.R. 390 (1983).

51. The OCS Lands Act gives the Secretary of the Interior the authority to reduce to zero the royalty rate on leases sold with the traditional auction, to encourage high-cost production. 43 U.S.C. $\S 1337$ (3) (Supp. IV 1980). But, to date the Secretary has not exercised this authority on active leases, presumably because of the administrative and political problems that he would encounter.

52. "Through the 1978 Amendments, Congress sought to experiment with alternatives to the traditional bidding system." 454 U.S. at 154.

53. Noting in Section II the list of undesirable properties of the work-commitmentbid auction, one is tempted to speculate that these properties could have led the Secretary to bypass that category of auction in fulfilling the congressional directive. See supra text accompanying notes $46,51-52$.

54. For example, one investigation of alternative methods of airport-slot allocation combines economic theory, field data, and experimental data. See Grether, Isaac \& Plott, The Allocation of Landing Rights by Unanimity Among Competitors, 71 AM. ECON. Rev. 166 (1981).

55. 43 U.S.C. § 1337 (a)(5)(B) (Supp. IV 1980).

56. 43 U.S.C. \& 1337 (a)(9) (Supp. IV 1980).

57. Firms also make selection decisions even when only one auction process is offered. That is, if all tracts are offered using auction process $A$, some firms will choose not to bid at all. And, if all tracts are offered using auction process $B$, some firms, although perhaps not the same set, will choose not to bid at all. The set of bidders is an important property of an auction, and finding out the nature of their decisions does not constitute a "bias." But, if the field experiment's randomizing requirements imply that auctions $A$ and $B$ will be used concurrently to test which one should be used in the future, self-selection bias between the two kinds can determine the experiment's results. The sets of bidders when $A$ and $B$ are offered concurrently will not necessarily match the selection decisions when only one of the two auction processes is available.

58. See, e.g., the works cited supra notes $3,27$.

59. We can capture in the laboratory the decisions of firms to bid or not to bid when only one auction process is available, see supra note 57 , while eliminating the inter-auction, self-selection biases. Of course, if one were interested in a multiple-auction environment in which self-selection between different kinds of auctions is a relevant feature, then we could also provide for this sort of variation in the laboratory. The key aspect is the control and flexibility of laboratory experiments in determining the selection decisions that are available. 
60. For a comprehensive discussion of many different auction methods and their history and uses, see R. Cassady, supra note 3.

61. Id. at 26.

62. Id. at 28.

63. Id. at 60-61.

64. See infra text accompanying notes 83-85.

65. Vickrey, supra note 27, at 20.

66. R. CASSADY, supra note 3 , at 152-53.

67. Vickrey, supra note 27, at 21.

68. R. Cassady, supra note 3 , at 71 .

69. Id. at 71. R. CAssady cites Rex v. Taylor, M'Cle. 362, 148 E.R. 141 (1824), in which this scheme was used.

70. See infra text accompanying notes 86-89.

71. To illustrate these comments further, imagine an auction in which two items are offered for sale, a new Cadillac and a new Chevrolet. Everyone knows which item is being offered. If all would be willing to pay more for the Cadillac, then this preference, is consistent with the second assumption, as long as no one is willing to pay more, because of what some other bidder is willing to pay. Now, suppose that a "blind" auction is conducted, in which the item is guaranteed to be either a Cadillac or a Chevrolet, and that some bidders know that the car is white, and others know that it is a four-door sedan. Further, suppose that it is known that Cadillacs are much more likely to be white than are Chevrolets, and that Cadillacs are slightly more likely to be four-door sedans than are Chevrolets. Clearly, each bidder's willingness to pay for the "blind" item will now depend on which of the two kinds of information he possesses and on his assessment of the relevant probabilities. Furthermore, knowing that some other person is willing to pay more suggests that that person has better information (white versus four-door) or a better assessment of the information's implications. The OCS auction is like this "blind" auction in that the characteristics of the auctioned item are unknown, but they can be estimated imperfectly, based on information that is obtainable. The theory of auctions with these information characteristics has been studied (see, e.g., J. Ramsey, BIDding and Oil. Leases (1980)), but this theory, and the performance of such auctions, has yet to be subjected to an experimental examination similar to that which has been applied to the standard auctions.

72. See supra text accompanying notes 26-29.

73. That price and efficiency considerations may be in conflict implies that the government's goal of maximizing revenue (to provide a "fair" return to the public) may be in conflict with maintaining or increasing competition, since efficiency is an important attribute of competitive outcomes.

74. See infra text accompanying notes 94-96.

75. An "after-market exchange" is one that is immediately motivated by the results of the primary auction. Further exchanges long after the primary auction are likely, because of new information affecting values, but they provide little concrete evidence of inefficiency.

76. See infra text accompanying notes 103-104.

77. To the extent that the government desires to promote OCS competition and its concomitant efficiency of allocation, after-market exchange should be welcomed. To the extent that the government's object is to maximize revenue from the sale of OCS leases, after-market exchange implies that the primary auction captures less than the full-revenue potential. But of course, it may not be possible to design an auction that maximizes revenue and that is also always efficient.

78. Mathematically, we can illustrate the effect of risk aversion thus: let the utility of the surplus, $v-b$, to a winning bidder be $(v-b)^{r}$, such that $0 \leq r \leq 1$. If $r=1$, then the bidder is risk neutral. The smaller is $r$, the more risk averse is the bidder. If $G(b)$ is the probability that a bid in the amount of $b$ will win, then the bidder's expected utility is $U(b)=(v-b)^{r} G(b)$. If $r=1$, then the optimal bid, at which the derivative $U^{\prime}(b)=0$, occurs at a value for $b$, such that $(v-b) G^{\prime}(b)=G(b)$; that is, the bid equates the expected marginal gain 


\section{Supreme Court Economic Review}

from the increased chance of winning with the expected marginal loss of surplus. If $r<1$, then the optimal bid occurs at a value for $b$ such that $(v-b) G^{\prime}(b) / r=G(b)$. Consequently, the effect of increased risk aversion (decreased $r$ ) is to increase the relative value (utility) of the expected marginal gain, and this increases the optimal bid. The more risk averse a bidder, the greater is the subjective weight given to the marginal gain from an increased chance of winning in the trade-off between this gain and the marginal loss in surplus, and thus the greater is the bid that balances these two components.

79. Vickrey, supra note 27 , at $16-17,20,29-30$.

80. Cox, Roberson \& Smith, supra note 27, at 10-13.

81. See K. Boulding, Economic Analysis 42 (rev. ed. 1948), and R. Cassady, supra note 3 , at 67 .

82. See supra note 78. In the Dutch auction it is optimal to stop the clock at the price $b$, such that $(v-b) G^{\prime}(b) / r=G(b)$, and therefore one's bid "should" be the same as in a firstprice auction.

83. See Cox, Roberson \& Smith, supra note 27, at 6-8; Milgrom \& Weber, supra note 3, at 1095; and Vickrey, supra note 27, at 20.

84. See Vickrey, supra note 27 , at 20.

85. Mathematically, in contrast with supra note 78 , surplus to the winning bidder is $v-x$, such that $x$ is the (uncertain) second highest bid. If $F(x)$ is a person's subjective probability that the second highest bid is less than or equal to $x$, then the expected utility from a bid of $b$ is $U(b)=\int_{0}^{b}(v-x)^{r} d F(x)$. The optimal bid $b$ must satisfy $U^{\prime}(b)=(v-b)^{\prime} F^{\prime}(b)=0$, which implies that $v-b=0$, or $b=v$, provided that the bidder believes that increasing $b$ will increase the probability that the bid $b$ will win; that is, $F^{\prime}(b)>0$. Notice in particular that this result is independent of $r$; it is also independent of the utility function and it only requires the assumption that "more (surplus) is better" for the bidder.

86. As in Cox, Roberson \& Smith, supra note 27, at 10-12.

87. R. CASSADY, supra note 3 , at 150-51. 179 (1852).

88. R. CASSADY, Id. cites other examples, as in Conover $v$. Walling, 15 N.J. Eq. 173,

89. Milgrom \& Weber, supra note 3, at 1095, 1100-1111.

90. See supra text accompanying notes $14-29 \&$ n.21.

91. See supra text accompanying notes 28-29.

92. See the descriptions of the experimental procedures in Coppin $\rightarrow$ Smith \& Titus, Incentives and Behavior in English, Dutch and Sealed-Bid Auctions, 18 ECON. INQUIRY 1, 4-5, 12-13 (1980), and in Cox, Roberson \& Smith, supra note 27, at 14-20, 34-42.

93. For example, the payoff potential per subject was lower, the Dutch-price decrement larger, and the speed of price decline much slower than in the other Dutch auctions.

94. Coppinger, Smith \& Titus, supra note 92, at 19.

95. 43 U.S.C. § 1332(3) (Supp. IV 1980).

96. See supra text accompanying notes 85-92.

97. See R. Cassady, supra note 3 , at 179-92, for several citations involving antiques, fish, timber, and wool.

98. D. Coursey, R. Isaac \& V. Smith, Natural Monopoly and the Contestable Markets Hypothesis: Some Experimental Results 33 (1982) (Discussion paper, University of Arizona Dept. of Economics).

99. Zonana, Boeing's Sale to Delta Gives It Big Advantage over U.S. Competitors, Wall St. J., November 13, 1980, at 1, col. 6.

100. The origin of the term "ring" appears to be that in "knockdown" sales in which the conspiring buyers resell the item to one of their group, the members formed a circle, or "ring," around their leader or organizer to facilitate the surveillance of each member by the others, and thus to assure an open after-market auction for determining the ring's profits from the agreement, See R. CASSADY, supra note 3, at 177, 182-83. 
101. But, as we note earlier, announcement of the winning bid facilitates an efficient after-market exchange if the original award is inefficient. See supra text accompanying notes 75-77, 96-97.

102. Vickrey, supra note 27, at 22.

103. See Rassenti, Smith \& Bulfin, supra note 37, which proposes the combinatorial auction and examines its performance characteristics using experimental methods.

104. Id. at 407-412.

105. See supra text accompanying notes 38-52.

106. See supra text accompanying notes 49-52.

107. See supra text accompanying notes 49-51.

108. See supra text accompanying notes 55-58.

109. See supra text accompanying notes 92-96. 